\title{
Wealth Effects on Household Final Consumption: Stock and Housing Market Channels
}

\author{
Yener Coskun ${ }^{1, *(1)}$, Burak Sencer Atasoy 2 (D) , Giacomo Morri $^{3}$ and Esra Alp ${ }^{4}$ \\ 1 Capital Markets Board of Turkey and Middle East Technical University, Eskişehir Yolu 8.Km No:156, \\ Ankara 06530, Turkey \\ 2 Turkish Treasury, Inonu Blv. No 36 Emek, Ankara 06510, Turkey; burak.atasoy@hazine.gov.tr \\ 3 SDA Bocconi School of Management, 20136 Milano, Italy; giacomo.morri@sdabocconi.it \\ 4 Economics Department, Social Sciences Institute, Dokuz Eylül University, Izmir 35160, Turkey; \\ eesraalpp@gmail.com \\ * Correspondence: ycoskun@spk.gov.tr
}

Received: 22 December 2017; Accepted: 22 May 2018; Published: 5 June 2018

\begin{abstract}
The study primarily explores the linkage between wealth effects, arising from stock and housing market channels, and household final consumption for 11 advanced countries over the period from 1970 Q1 to 2015 Q4. As a modelling strategy, we employ regression analysis through the common correlated effects mean group (CCEMG) estimator, as well as Durbin-Hausman cointegration and Dumitrescu and Hurlin (2012) causality tests. The study provides various pieces of evidence through whole-panel and country-level analyses. In this respect, we find that consumption is mostly explained by income and housing wealth is positively and significantly correlated with consumption. As counter-intuitive evidence, we detect a negative linkage between consumption and stock wealth. The evidence also suggests a long-run cointegration relationship among consumption, income, interest rates, housing wealth, and stock wealth. Moreover, we find bidirectional causality between consumption and income, stock wealth, housing wealth, and interest rates. Overall, the evidence implies that housing wealth, rather than stock wealth, is the primary source of consumption growth in advanced countries.
\end{abstract}

Keywords: consumption; housing wealth; stock wealth; asset transmission; CCEMG

JEL Classification: D12; E21; R31

\section{Introduction}

The asset price-driven consumption-wealth effect pattern has long been an important economic phenomenon; also, making stock and housing markets major asset classes ${ }^{1}$ is key for economic policies specifically for advanced countries. The transmission mechanisms from asset markets to the real economy have various dimensions and are complicated to analyse. Specifically, after the distortions arising from the stock and housing market-based Keynesianism of the US after the 2000s, there has been a hot debate in the finance and housing literature on which/how asset prices affect economic growth through the consumption channel and their potential drawbacks. The literature reveals that the relations among consumption, income, wealth, interest rates, and economic growth are the major issues in economics. Keynes (1936) indicates that the amount of aggregate consumption mainly depends on

1 For example, the aggregated values of the US housing stock and market capitalization of listed companies were 29.6 trillion USD and 27.3 trillion USD, respectively, in 2016. Available at: www.housingwire.com/articles/38852-zillow-total-value-of-ushousing-reaches-all-time-high; https:/ / data.worldbank.org/indicator/CM.MKT.LCAP.CD (accessed on 16 October 2017). 
the amount of aggregate income. Friedman (1957) suggests that income is generally defined as the amount that a consumer unit could consume while maintaining its wealth intact. As also suggested by the life cycle and permanent income hypotheses, growing financial and housing assets are most likely to induce consumption. Housing and stock markets are major sources of wealth in developed countries in particular (Poterba 2000; Iacoviello 2011).

This paper addresses two complementary sets of questions. The first concerns the components of consumption. We specifically explore the role of housing and stock wealth in consumption. Do changes in stock and housing market indexes, as proxies for stock and housing wealth, matter for the consumption level? Also, what are the additional variables to explain consumption? Does elasticity of consumption spending give a larger response to specific wealth types? Do the responses to consumption change depending on the financial structure, such as a market-based or a bank-based structure, or the size of the economy? The second set of questions concerns the attempts to measure the long-term and causal relations among variables. Is there a long-term and causal relationship between consumption and each model variable, such as income, interest rates, housing wealth, and stock wealth?

In this respect, the study primarily investigates how household real per capita final consumption expenditure responds to changes in housing wealth and stock wealth for 11 advanced OECD countries-Australia, Canada, Finland, France, Italy, Japan, New Zealand, Sweden, Switzerland, the UK, and the US-over the period 1970 Q1 to 2015 Q4. This paper attempts to conduct detailed econometric analyses. In this respect, we first detect cross-sectional dependence in the data by employing CD and bias-adjusted LM tests. After detecting cross-sectional dependence, we employ the cross-sectionally augmented IPS (t-bar) (CIPS) (Pesaran 2007) panel unit root test and then the second-generation Durbin-Hausman test advanced by Westerlund (2008) to test the cointegration. Subsequently, by performing Pesaran and Yamagata (2008) test, we explore the slope heterogeneity. After defining the data as cross-sectionally dependent and heterogeneously sloped, we use the common correlated effects mean group estimator (CCEMG) introduced by Pesaran (2006) to estimate the coefficients. As a robustness check, we re-estimate the models utilizing the two-stage least-squares (2SLS) and generalized method of moments (GMM) methodologies. Finally, we employ the Granger causality test introduced by Dumitrescu and Hurlin (2012) to explore the causal relationship between our variables.

This paper empirically extends the prior literature along several dimensions. First, from the methodological perspective, to the best of our knowledge, this is the first paper to investigate the consumption-wealth effect nexus using the CCEMG estimator. Moreover, income and wealth components have generally been used as the main variables in the empirical literature; the study additionally employs interest rates to explain consumption. Second, the observation period (1970-2015) and the number of analysed countries help to form one of the largest and most up-to-date clusters in the existing empirical literature. Third, the long observation period also helps us to analyse the impact of big economic events in recent economic-financial history and to test the consumption function in the long run. Therefore, the study provides an interesting framework with which to test the interactions between consumption and stock and housing markets' wealth channels during major economic/financial periods. Fourth, the study provides a comparative knowledge set by employing the data of 11 advanced economies. This contribution may also be interesting, because these countries represent different economic foundations in advanced economies in terms of their size, financial structure (bank-based vs. market-based), and geographic diversity.

The remainder of the paper is organized as follows. The next section documents the theoretical and empirical literature review. Section 3 explains the data and modelling strategies. The empirical results and implications are discussed in Section 4. Finally, Section 5 concludes. 


\section{Theoretical and Empirical Literature Review}

\subsection{Consumption Theory}

The study of the consumption function has undoubtedly yielded some of the highest correlations, as well as some of the most embarrassing forecasts in the history of economics (Modigliani and Brumberg 1954). The measurement of the wealth and consumption linkage dates back to Ando and Modigliani (1963) in the modern finance era. Several studies (among others, Ibrahim 2010; Lee et al. 2017) about the correlation between stock and house prices have not taken into account the correlated effects in consumption. Some studies (among others, Ibrahim and Habibullah 2010) have analysed the correlation between the stock market and the aggregate consumption without considering the effects of the housing sector, whereas others (among others, Attanasio et al. 2009) have analysed the correlation between the housing market and the aggregate consumption without considering the effects of the stock market. Finally, several authors (among others, Poterba 2000; Lettau and Ludvigson 2004) have investigated the impact of wealth on consumption. These studies found that a dollar increase in the aggregate wealth leads to an increase in the aggregate consumption of $\$ 0.03$ to $\$ 0.05$. To ensure a sound theoretical and empirical analysis, we will first review the theoretical foundations of the consumption function.

There has been a long debate on the determinants of consumption behaviour since Keynes (1936) developed a model of consumption theory. According to Keynesian theory, consumption ${ }^{2}$ is a function of income in terms of wage units and the propensity to consume. The principal objective factors that influence the propensity to consume appear to be the following, as stated in Keynes's general theory: (i) a change in the wage unit, (ii) a change in the difference between income and net income, (iii) windfall changes in capital values, (iv) changes in the rate of time discounting, (v) changes in the fiscal policy, ${ }^{3}$ and (vi) changes in expectations. Keynes (1936) stated that expectations regarding future income and future prices have an impact on today's consumption. If there is considerable uncertainty, its effect will be greater. As a consequence of these statements, in a given situation, the propensity to consume can be considered substantially as a stable function, under the condition that changes in the wage unit in terms of money have been eliminated. Defining what Keynes called the propensity to consume as the functional relationship between $Y w$, a given level of income in terms of wage units $(W)$, and $C w$, the expenditure on consumption out of that level of income, the consumption function can be expressed as below (Keynes 1936):

$$
C w=(Y w) \text { or } C=W(Y w) .
$$

After Keynes established his general theory, a different theory, called the relative income theory of consumption, was suggested by Duesenberry in 1949. In his analysis, Duesenberry (1949) defined current consumption as being influenced not merely by the current level of absolute and relative income but also by the levels of consumption gained in the previous period. Duesenberry put forward the theory of consumer behaviour based on the relative income of an individual rather than on his or her absolute income as a determinant of his or her consumption.

In conjunction with the Keynesian notion, consumption theory has evolved into more complex models in recent years. Modern consumption theory extends the static theory of the consumer to an intertemporal setting to explain an individual's choice of consumption or saving and perhaps leisure over time (Mariger 1986). Two essential modern consumption theories were developed after Keynes.

2 Keynes (1936) also examined the definition of the line between consumer purchasers and investor purchasers. A problem occurs when it comes to distinguishing whether purchasing behaviour is a consumer purchase, such as a motorcar, or an investor purchase, such as a house. Considering purchasers properly becomes even more important when the influence on the propensity to consume is taken into consideration.

3 Keynes (1936) stated that income taxes are as relevant as the rate of interest, while the changes in the fiscal policy may be greater, in expectation at least, than in the rate of interest itself. 
The first is Friedman (1957) 'permanent income theory', and the latter is the 'life cycle theory' by Modigliani and Brumberg (1954) and Ando and Modigliani (1963). As Dornbusch and Fischer (1990) stated, these two theories are quite similar. Like much good macroeconomics, they have in common careful attention to microeconomic foundations. The life cycle theory in particular starts from an individual's lifetime consumption planning and develops from that a macroeconomic theory of consumption and saving. This theory views individuals as planning their consumption and saving behaviour over long periods with the intention of allocating their consumption in the best possible way over their entire lifetime. The consumption function can be written as follows according to the life cycle theory with reference to Dornbusch and Fischer (1990):

$$
C=a W R+c Y L
$$

in which WR is real wealth, $a$ is the marginal propensity to consume out of wealth, $Y L$ is the labour income, and $c$ is the marginal propensity to consume out of the labour income.

The life cycle model suggests that people save during their working lives and run down this wealth during their retirement period. Therefore, individuals plan to use both labour income and financial and non-financial assets for their lifetime consumption. In this framework, financial and non-financial assets are regarded as stock market wealth and housing wealth, respectively. When the prices of these assets change, although the labour income is still the same, an increase in wealth will occur; hence, individuals will remake their plans for their lifetime consumption. As discussed broadly from various perspectives below, this mechanism creates transmission channels that are effective on aggregate consumption.

\subsection{Behaviours of the Stock and Housing Wealth Channels in Consumption}

\subsubsection{Differences between Housing and Stock Wealth Effects}

Ludwig and Sløk (2002) summarized (Friedman 1957; Ando and Modigliani 1963; Modigliani and Brumberg 1979; Romer 1990; Poterba 2000) the three transmission channels common to both stock market wealth and housing wealth: (i) the realized wealth effect, (ii) the unrealized wealth effect, and (iii) the liquidity constraints effect. The authors further indicated that, while the stock option value effect and uncertainty effect are the particular wealth transmission channels for the stock market, budget constraints and substitution effects are the additional housing wealth channels.

The short/long-term variations and the magnitude of the wealth transmission channels depend on various factors. Typically, changes in the macroeconomic conditions or economic policies may have an impact on asset prices, wealth, and consumption behaviour. For example, a decline in the general level of prices will clearly raise the real value of the community's stock of money and government bonds, since the nominal value of these assets will not decrease. Thus, the real value of the community's total assets will rise. This will lessen the need for additional savings and hence increase the fraction of any given level of real income that the community will wish to consume (Friedman 1948). Based on the fluctuations in the general level of prices, the community's financial and real assets, such as house assets, will rise in value. This increase in wealth will result in higher consumption depending on positive expectations about future inflation rates (Bootle 1981) and intertemporal substitution of leisure and consumption.

However, despite some common wealth transmission channels, the literature has also revealed that the impacts of stock and housing market wealth on consumption may show differences depending on the various reasons (Poterba 2000; Bajari et al. 2003). Case et al. (2001) discussed many reasons why consumption may be affected differently by the form in which wealth is held. Case et al. (2005) also underlined that real estate and housing wealth should have a different impact from stock market wealth on consumption. Ludwig and Sløk (2002) stated that housing and stock as asset classes have different risk characteristics and, as with stocks, the marginal propensity to consume out of unrealized gains in housing wealth might be lower. Tsai et al. (2012) showed that the housing and 
stock markets respond rather differently to negative shocks when the stock market is more volatile, but price rigidity is found in the housing market. Apergis et al. (2014) indicated that the impacts of housing wealth on consumption may involve a rather complex mechanism. From the behavioural perspective, Shefrin and Thaler (1988) indicated that the psychology of framing may dictate that certain assets are more appropriate to use for current expenditures, while others are earmarked for long-term savings. ${ }^{4}$ Kennickell and Starr-McCluer (1997) found that households have imperfect knowledge of their financial wealth and thus may not react instantaneously to changes in wealth. Aoki et al. (2004) noted that, if consumers are optimistic about their economic prospects, they are likely to increase their consumption of housing and non-housing goods alike.

\subsubsection{Housing Wealth Effect on Consumption}

The growing importance of the real estate and housing sector in particular in national economies may play a role in the housing wealth channel. In this respect, by calculating the total, backward, forward, internal, and sectoral linkages of the real estate sector, Song and Liu (2007) found that the real estate sector played a more important role in the economic development in Australia, Denmark, France, Japan, and the USA than in the Netherlands and Canada. Searle (2011) suggested that housing wealth is increasingly being used as a financial safety net across the life course and that different economic periods may have significant effects on housing-related behaviours. The impact of housing wealth may depend on several factors that are effective on house prices. In this respect, Catte et al. (2004) argued that house prices seem to be subject to larger oscillations in countries where the housing supply is relatively inelastic and where favourable tax treatment of mortgage interest encourages the leveraging of housing equity. Tsai et al. (2012) revealed a long-run equilibrium relationship between stock and housing markets and showed that the wealth effect of these markets is more significant when the stock price outperforms the housing price. Accordingly, a bull market induces an increase in the stock prices and subsequently creates wealth for investors. Simo-Kengne et al. (2013) suggested that house prices exhibit an asymmetric effect on consumption, with a positive effect following an increase in house prices being dominant in magnitude in comparison with a decline in consumption resulting from a negative shock to house prices.

The empirical literature has generally suggested a significant housing wealth effect with some counter results. In this respect, Mishkin (2007) discussed the idea that changes in housing wealth should be larger than equity, because housing wealth is spread much more evenly over the population than stock market wealth. The author also noted that higher house prices could even reduce current consumption for those planning to buy a house if they believe that they will need to save more to do so. The consumption effect of rising house prices is thus uncertain and subject to distributional effects, depending on who is gaining the increased housing wealth. Engelhardt (1996) identified the marginal propensity to consume out of housing wealth to be about $\$ 0.03$ per dollar, but he found this effect to be asymmetric and significantly associated only with declines in house values (so-called reverse wealth effects). Case et al. (2001), investigating the impact of the stock market as well as housing wealth using state-level panel data for the US in the period from 1982 to 1999, reported a higher coefficient estimate for housing wealth than for stock market wealth. Applying an error correction framework, Belsky and Prakken (2004) found that the estimated consumption effects of real estate and corporate equity are sizeable and similar in magnitude (about $\$ 0.05$ on the dollar) but different in the immediacy of their impact. Their findings suggested that about $80 \%$ of the long-run housing wealth effect is realized within one year, whereas it takes nearly 5 years for stock

4 Rapach and Strauss (2006) indicated that households may separate their wealth into different mental accounts, so changes in different categories have different effects on household consumption. Steinberg et al. (2002) reported that there are hints that psychological framing matters for consumption out of income (Arkes et al. 1995) and for making decisions (Andreoni 1995). Case et al. (2001) indicated that the emotional impact of accumulating stock market wealth may be quite different from that of real estate wealth, particularly owner-occupied housing. People are perhaps less aware of the short-run changes in real estate wealth, since they do not receive regular updates on its value. Stock market wealth can be tracked daily online or in newspapers. 
wealth to approach $80 \%$ of its long-run impact. Benjamin et al. (2004) and Kishor (2007) found that a surge in housing prices has a greater effect on consumption than a stock price increase: whilst a $\$ 1$ increase in financial wealth leads to an average $\$ 0.03 / \$ 0.05$ extra consumption, the effect is $\$ 0.07-\$ 0.08$ for real estate wealth according to Benjamin et al. (2004) and Kishor (2007). Kishor (2007) also discovered that the housing wealth effect increased over the three previous decades in the US. Bostic et al. (2009) concluded that housing wealth in the US has a relatively larger effect on consumption than financial wealth variation. On the other hand, Carroll et al. (2011) analysed the short-run and long-run effects of housing wealth in the US. According to their findings, a $\$ 1$ change in the short-run movement and in the permanent movement in housing wealth increases the consumption respectively by $\$ 0.02$ and $\$ 0.09$. Furthermore, by analysing time series and microeconometric evidence on the relationship between stock and house prices and consumer spending, Paiella (2009) suggested that the relationship between wealth and consumer spending appears to be strong, but there is some disagreement regarding its size and nature. In this respect, the results concerning the relative sizes of the wealth effects are mixed. By underlining that housing wealth exceeds financial wealth in the US and Canada in different studies (see Davis and Palumbo 2001; Pichette and Tremblay 2003; Carroll 2004), Sierminska and Takhtamanova (2007) also found that the overall wealth effect from housing is stronger than the effect from financial wealth for Canada, Italy, and Finland. Dvornak and Kohler (2003) carried out the same analysis based on an Australian sample and found that, even though both the housing and the stock market wealth have a significant effect on Australian consumption, the former has a greater effect.

The magnitude of the housing (and stock) wealth effect has also been analysed from the perspective of the financial structure and the level of financial development. In this respect, in parallel to the findings of Ludwig and Sløk (2004) and Case et al. (2005), Slacalek (2009) found that the marginal propensity to consume out of housing wealth is quite high in the Anglo-Saxon, market-based, non-euro area economies with more complete mortgage markets. Building a panel of 14 emerging economies with quarterly data to estimate the magnitude of wealth effects on consumption, Peltonen et al. (2012) found that, while housing wealth effects are more important in countries with a low level of financial development or a low income level, financial wealth effects are stronger for countries with high stock market capitalization. On the other hand, Ludwig and Sløk (2004) suggested that the long-run responsiveness of consumption to permanent changes in stock prices is higher for countries with a market-based financial system than for countries with a bank-based financial system. Albacete and Lindner (2017) indicated that the elasticity of consumption to financial asset prices is often found to be larger in Anglo-Saxon countries than in continental Europe, where the financial asset holdings are substantially smaller (also see Edison and Sløk 2001; Paiella 2007).

Despite generally finding a positive linkage for the housing wealth effect, the empirical literature has also suggested counterarguments. In this respect, Muellbauer (2007) indicated that the housing wealth effect can be negative for prospective first-time home buyers. Boone and Girouard (2002) and Slacalek (2009) found negative values for the marginal propensity to consume out of housing wealth for Italy. Helander (2014) and Zhou et al. (2015) found a negative housing wealth effect for Finland and China, respectively.

\subsubsection{Stock Wealth Effect on Consumption}

As shown in the empirical literature, the stock wealth effect on consumption can be statistically significant (positive or negative) or insignificant depending on the empirical settings. In this respect, a positive and greater stock market wealth effect is possible depending on the data and modelling structure. Using data with a quarterly frequency and for the period 1980 Q1-2007 Q4 for the euro area, Sousa (2009) found that the financial wealth effects are relatively large and statistically significant, housing wealth effects are virtually nil and not significant, and consumption growth exhibits strong persistence and responds sluggishly to shocks. Utilizing quarterly data, spanning from 1972 Q4 to 2012 Q4, Barrell et al. (2015) provided evidence that housing wealth plays no role in Italy but is significant in the UK. In both countries, financial wealth exerts a positive and significant impact on aggregate 
consumption, and by and large the housing wealth effect assumes relatively increasing importance over time in the UK, while for Italy this is true for the financial wealth effect.

From a theoretical perspective, a major problem with consumption as an explanatory factor for changes in stock prices is its relative stability over time (Asprem 1989). In the short term, the marginal propensity to consume seems to be constant (Keynes 1936; Kuznets 1946; Dornbusch and Fischer 1990), but stock prices may change rapidly. Consumption connected to stock market wealth may show asymmetric behaviours depending on several factors. In this respect, Boone et al. (1998) stated that, as illustrated in 1987, monetary authorities have sometimes reacted relatively quickly to sharp drops in stock market values by lowering policy-controlled interest rates, thereby counteracting the potential negative wealth effects on households. Bertaut (2002) indicated that consumption responses to wealth will be smaller in countries where the ratio of wealth to consumption is lower or where a smaller share of financial wealth is held in the form of equity. As shown by Kishor (2007), consumption can react to permanent wealth movements, with almost half of financial wealth being generated by transitory shocks. In this respect, the ECB (2009) argued that the levels of volatility in housing and financial wealth may influence the extent to which euro area households perceive the respective movements in wealth as permanent versus transitory. Carroll et al. (2011) also discussed whether high-frequency fluctuations (volatility) in financial wealth may cause a substantially lower marginal propensity to consume out of financial wealth, and this feature should explain subsequent spending patterns. Helander (2014) concluded that the distribution of wealth and debt in an economy is important in explaining how aggregate consumption reacts to sudden changes in wealth or income. Some studies have also suggested that wealthier households hold most of the financial wealth but that their consumption is not highly sensitive to gains in financial wealth with a low marginal propensity to consume (i.e., see Pichette and Tremblay 2003; Kishor 2007). Fereidouni and Tajaddini (2015) asserted that consumer confidence changes the direction of the association between financial wealth and total consumption and makes the previous positive link between financial wealth and total consumption negative.

In line with the above background, some empirical studies have shown that there may be a negative stock wealth effect. In this respect, fluctuations in share prices and crises may have potentially negative impacts on stock prices and their wealth effect. Apergis et al. (2014) reported that, while conventional macroeconomic models are favourable to the importance of asset wealth in stimulating household spending, there is concern that a slowdown of equity prices may lead to a decrease in consumption spending and subsequently to an economic recession. Poterba and Samwick (1995) suggested that the 1987 stock market crash had a smaller negative effect on consumption growth. When analysing the impact of the 1929 crisis on consumption, household spending on durables declined more than that on non-durables, which remained robust until 1932. Some empirical studies have suggested that a negative stock wealth effect is possible under some circumstances. For example, Asprem (1989) showed that stock prices are negatively correlated with imports perceived as a measure of consumption. In this respect, the author found a significant negative relationship between imports and the stock market in France, Germany, and the UK. This supports the relationship that was found between stock prices and consumption. Consistent with Poterba and Samwick (1995) and Vissing-Jørgensen (1999), Dynan and Maki (2001) found that stock returns appear to have a negative and statistically significant effect on the consumption growth of non-stockholders. However, the estimated relationship between the stock returns and the consumption growth of stockholders is positive, stronger when the group is limited to those with greater holdings, and statistically significant at or close to the 5 per cent level. Sierminska and Takhtamanova (2007) summarized the literature based on a lack of financial wealth in countries depending on the data set used, such as aggregate, state-level, and household-level data. Depending on the modelling strategies, Slacalek (2009) found mixed wealth effect results in country-level estimates also involving an insignificant and negative stock market wealth effect. Case et al. (2011) concluded that the estimated coefficient for stock market wealth has a negative sign. 
Therefore, various factors may contribute to the unclear movements of housing and stock wealth components in consumption, such as differences in stock and housing as the asset classes, the share and distribution of stock/housing wealth, volatility, permanent or transitory perceptions of the movements of wealth types, behavioural aspects of decision making regarding consumption based on housing and stock market wealth movements, short/long-term economic and financial expectations of consumers, institutional and policy differences among countries, the level of financial development, and so on.

\subsection{The Effects of Other Variables and Interest Rate on Consumption}

In addition to variables suggested in the consumption theory such as income and wealth, empirical literature reveals that consumption may depend either directly or indirectly on a number of economic variables, such as the unemployment rate (Skalin and Teräsvirta 2002), gross national product (Van Dijk et al. 2002), interest term structures (Floden 2001), and changes in monetary policy (Aftalion 1997). Furthermore, slow macroeconomic fluctuations and the presence of liquidity constraints (Hall and Mishkin 1982; Jaffee and Stiglitz 1990) can affect consumption behaviour (Jawadi et al. 2015). Among these variables, interest rate is of particular interest in the empirical literature. During the 1970s and 1980s, serious attempts were made to estimate the effect of nominal interest rates and inflation on aggregate consumption and saving in the US (Paradiso et al. 2012). From theoretical perspective, Keynes (1936) discussed how it was convenient to suppose negative relations between consumption and interest rates according to classical theory; but it has long been recognized that the total effect of changes in the rate of interest on the readiness to spend on present consumption is complex and uncertain. Also, the usual type of short-period fluctuation in the rate of interest is unlikely to have much direct influence on spending either way. Empirical literature also reveals that the evidence is mixed for the impact of interest rates on consumption. Campbell and Mankiw (1989) found that expected real interest rates are not associated with expected changes in consumption. For Germany, Hansen (1996) provided evidence that interest rates can influence only the short-run dynamics of consumption; the long-term trend of private consumption is determined by other variables. Kapoor and Ravi (2009) discussed the fact that most previous studies have found small effects of interest rates on consumption and saving (Hall 1988); however, it remains unclear whether the interest rate elasticities are truly small (see, Springer 1977; Howard 1978) or whether these findings are spurious due to endogeneity of interest rates or measurement problems, like the difficulty of observing the household-specific interest rate (also see, among others, Aye et al. 2012; Inglesi-Lotz et al. 2012). MacDonald et al. (2011) found that the effect of the nominal interest rate on consumption is asymmetrical. Declines in the interest rate had larger effects on consumption than increases in the rate of interest. However, the effects of only decreases in the rate of interest are found to be statistically significant. Kerdrain (2011) found that the effect of interest rates on consumption is not clear for the Euro area, and this may arise from heterogeneity across countries. The author also indicated that the positive coefficient on the interest rate should be interpreted as an income effect, and appears necessary to have strong cointegration. For a panel of quarterly data for 14 advanced economies spanning 1998 to 2012, Jaramillo and Chailloux (2015) found a significant long-term relationship between consumption and the different components of income and wealth. The authors also attempted to employ the ECB's mortgage lending rate for new borrowing, as well as the long-term lending rate for new borrowing, and did not find statistically significant results. Di Maggio et al. (2017) reported that lower interest rates are generally thought to affect firms' investment and households' consumption by reducing the cost of external finance. Moreover, isolating borrowers' consumption and saving responses to a change in the interest rate is complicated, because interest rates and refinancing decisions are endogenous and depend on a household's finances and creditworthiness.

However various studies, for example Ludwig and Sløk (2004), Case et al. (2005, 2011), Apergis et al. (2014), Jawadi et al. (2015), and Zhou et al. (2015), employ income, stock wealth, and housing wealth as explanatory variables for consumption; we also employ short-term interest rates as the additional variable in our modelling in parallel to some of the studies in the literature 
such as Hansen (1996), MacDonald et al. (2011), Kerdrain (2011), and Jaramillo and Chailloux (2015), among others.

\subsection{Modelling Dimensions in the Empirical Literature}

As discussed previously, aggregate consumption has already been investigated by many authors, with different research features and objectives. The theoretical literature has generally revealed that the greater the permanent wealth increase is, the higher the householder/shareholder consumption expenditure is. However, investigations into the correlations between housing and financial wealth and household final consumption have suggested mixed results depending on various factors. In this respect, the different outcomes in studies may also be explained by the differences in modelling strategies involving the testing methodology, data cluster, and analysis period. ${ }^{5}$

In this respect, different clusters have been used in the previous studies. Hui et al. (2012) analysis relied only on the Hong Kong market, using data from 1981 to 2010. Apergis et al. (2014) adopted aggregate time-series data from South Africa over the period 1995 to 2011. Simo-Kengne et al. (2013) used the panel vector autoregression approach to provincial-level panel data covering the period 1996-2010 for South Africa. Vizek (2011) analysed the links among stock market wealth, housing wealth, and aggregate consumption for a sample of four European post-transition economies (Bulgaria, Croatia, the Czech Republic, and Estonia) from 1996 to 2010. Ludwig and Sløk (2004) used a larger cluster involving 16 OECD countries from 1960 to 2000. Case et al. (2001), Benjamin et al. (2004), Kishor (2007), Bostic et al. (2009), and Carroll et al. (2011) relied on a US cluster, whereas Dvornak and Kohler (2003) studied the Australian market. In this paper, to obtain a reliable outcome, we employ one of the largest clusters by utilizing quarterly data, spanning from 1970 Q1 to 2015 Q4, for 11 advanced countries.

Another difference, as mentioned above, is represented by the method used to process data. The empirical literature suggests that several methodologies were employed to explore the consumption-wealth effect linkage. For example, Dvornak and Kohler (2003) used a standard model based on the LC-PIH model as described by Blanchard and Fisher (1989). Bostic et al. (2009) implemented a constrained marching procedure and then a bootstrapping procedure to guard against the possibility that an idiosyncratic match might drive the results and to obtain a measure of confidence regarding the robustness of the parameter estimates. Kishor (2007) used the Gonzalo and Ng (2001) variance decomposition framework. In Benjamin et al. (2004) study, the serial correlation was tested using the Breusch-Godfrey Lagrange multiplier (LM) test. Finally, Ludwig and Sløk (2004) used the PMG model (pooled mean group) proposed by Pesaran et al. (1999).

As one of the modelling dimensions, it seems that cointegration methods have frequently been used in the literature. Gali (1990) estimated cointegrating regressions between aggregate labour income and aggregate consumption and between aggregate labour income and aggregate non-human wealth, as well as three statistics corresponding to residual-based cointegration tests. He concluded that cointegration cannot be established formally for either pair of variables as the weakening evidence for the life cycle model. Carroll et al. (2011) also applied the cointegration methodology but stated that cointegration methods are problematic for estimating wealth effects. Conversely, Vizek (2011) relied on the Johansen procedure to determine whether the aggregate consumption forms an equilibrium relationship with income, stock market, and housing wealth in the long run. The authors found evidence that supports the presence of the long-run wealth effect in Bulgaria, Croatia, and the Czech Republic. By investigating the long-run relationship between private consumption, disposable income, and wealth approximated by equity and house price indices for a panel of 15 industrialized countries, Dreger and Reimers (2012) found that consumption, income, and wealth are cointegrated in their

5 As discussed by Jawadi and Sousa (2014), in the light of the nature of the variables and the complexity of the adjustments between consumption and wealth, the current state of the art has not provided unanimous conclusions yet. Apergis et al. (2014) also noted that the wealth effect on consumption has been studied extensively, and that mixed conclusions have been reported depending on the sources of wealth and methodology used. 
common components and that the impact of house prices exceeds the effect arising from equity wealth. Hui et al. (2012) confirmed the cointegration relation between private consumption, income, housing wealth, and stock wealth by using the bounds-testing procedure. In this respect, the ARDL cointegration results imply that housing wealth exerts more significant and profound effects than stock wealth for Hong Kong. By employing the panel cointegration procedure of Pedroni (1999), Apergis et al. (2014) found a cointegrating relationship between consumption, income, and wealth that might be interpreted as a long-run consumption function.

The consumption-wealth effect literature also involves causality analysis as another modelling dimension. In this respect, Shirvani et al. (2012) performed bilateral Granger causality tests for US stock prices, home prices, and private consumption and found the presence of bilateral causality between stock prices and home prices and between stock prices and consumer spending. The results show unilateral causality from home prices to consumer spending. These findings support the reinforcing effects of stock and home price movements on private consumption, as well as the feedback effect of consumer spending on stock prices. Apergis et al. (2014) identified the presence of bidirectional causality between consumption and income, suggesting that both variables are endogenous. With respect to the wealth variables, they found unidirectional causality running from both forms of wealth to consumption. Ohman and Yazdanfar (2017) investigated the Granger causal link between the stock market index and the housing prices in Sweden using monthly data from September 2005 to October 2013. They found that the stock market index and housing prices are co-integrated and that a long-run equilibrium relationship exists between them. According to the Granger causality tests, bidirectional relationships exist between the stock market index and the apartment and villa prices, respectively, supporting the wealth and credit price effects.

We employ the common correlated effects mean group (CCEMG) estimator, Durbin-Hausman cointegration test, and Dumitrescu and Hurlin (2012) Granger causality test beside other supportive models. As the contribution from the methodological perspective, it seems that cointegration and causality analysis have been used in the previous empirical studies, but this study will be the first to use the CCEMG estimator. More importantly, the study employs interest rates as the additional variable for the selected observation period and the cluster beside mainstream variables generally used in consumption-wealth effect literature.

\section{Data and Modelling Strategies}

\subsection{Data Description and Construction}

As summarized in the Appendix A, we employ household real per capita final consumption expenditures (consumption), net real per capita national disposable income (income), the real share price index (as a proxy for stock wealth), the real house price index (as a proxy for housing wealth), and nominal interest rates as the selected variables for the study. Below, we explain our criteria for variable selection and source/description/construction of the data by comparing our framework and that of similar studies.

We select countries based on several criteria, aiming to improve the diversity of the data through the size, structure, and geographic variation of the economies in line with the literature (i.e., see Slacalek 2009). Our decision to use the data of 11 advanced countries is also driven by data and modelling constraints. In this respect, we use relatively small advanced economies, such as Finland, New Zealand, Sweden, and Switzerland, as well as big economies, such as Australia, Canada, France, Italy, Japan, the UK, and the US. From the perspective of the financial structure of the economies, we employ bank-based economies, such as France, Japan, Italy, New Zealand, and Finland, as well as market-based economies, like the UK, the US, Switzerland, Australia, Canada, 
and Sweden (for the classification of the countries based on their financial structures, see Borio 1996; Demirgüç-Kunt and Levine 1999; Levine 2002; Ludwig and Sløk 2004). ${ }^{6}$

Accurate measuring of the housing and stock market wealth is the concern in the empirical literature. In this respect, Apergis et al. (2014) emphasized that the wealth effect on consumption has been studied extensively in the literature and that mixed conclusions have been reported depending on the sources of wealth, as well as the methodology used. Jawadi and Sousa (2014) also indicated that the lack of consensus regarding the definition of wealth is one of the reasons for the mixed results in the consumption-wealth effect literature (see, Buiter 2008; Calomiris et al. 2009). Case et al. (2001) stated that institutional differences among countries may result in less accurately measured housing prices and housing wealth. Dvornak and Kohler (2003) indicated that no consensus has been reached among authors about which type of wealth is easier to measure accurately. The authors also discussed the possibility that it may be easier to find information on current financial wealth than on current real estate wealth, as houses are less homogeneous and less frequently traded than shares. Mishkin (2007) also discussed his scepticism regarding the cross-country results in the literature, because they do not account for the fact that housing wealth effects should be expected to vary considerably across countries, given the substantial institutional differences in the structure of their financial systems and distributions of income and assets across households. Aron and Muellbauer (2013) indicated that much of the empirical literature assessing the wealth effect of house prices on consumption has been marred by poor control of the common drivers of both house prices and consumption.

Our various modelling attempts reveal that the results are very sensitive to the selection of explanatory variables, period, and countries. ${ }^{7}$ Because data on stock and housing wealth are not readily available in our modelling structure, we use share price and house price indices as proxies for stock wealth and housing wealth, respectively, in line with the empirical literature (e.g., Case et al. 2001; Bertaut 2002; Ludwig and Sløk 2004; ${ }^{8}$ Labhard et al. 2005; Carroll et al. 2011; Ciarlone 2011; Peltonen et al. 2012; Apergis et al. 2014). We also employ aggregate consumption data instead of using more refined consumption data, such as durable or non-durable consumption. The merit of this approach was discussed by Šonje et al. (2014) and indicated that the total (aggregate) consumption also includes expenditures on housing services, even though durable consumption goods are primarily spent on mortgage refinancing.

Quarterly data on consumption, the share price index, the house price index ${ }^{9}$, interest rates, and the consumer price index, as well as annual data on income, are obtained from the OECD database.

6 The linkage between financial structure and economic growth has been analysed broadly in the literature. In this respect, Demirgüç-Kunt and Levine (1999) found, with low statistical significance, that there is some indication that countries with more equal income distribution and higher growth are more likely to have market-based financial structures. Allen and Gale (2000) suggested that the importance of market-based financial intermediation tends to increase as the per capita GDP rises. However, Levine (2002) provided evidence that financial structure is not significantly related to economic growth, and the data used are consistent with the view that the legal system importantly influences financial sector development, and this in turn influences long-run growth. Demirgüç-Kunt et al. (2011) suggested that services provided by financial markets become comparatively more important as countries grow. Gambacorta et al. (2014) confirmed the widely accepted view that both banks and markets are very important for economic growth. However, the authors also found that there is a point after which further growth in financial activity no longer contributes to growth and may even slow it down.

7 It may be interesting to note that our modeling attempts generally suggest a strong housing wealth effect. But in general, choosing appropriate modelling features is a critical concern in the consumption-wealth effect empirical literature, and the modelling preferences may change the results substantially. For example, Ludvigson and Steindel (1999) indicated that modelling a trend in the cointegrating relationship between consumer spending, permanent income, and consumer net worth was not appropriate with any sensible model of consumer behaviour. Case et al. (2005) did not include lags in household housing wealth, given the strong serial correlation of home price changes, which would introduce substantial multicollinearity into the regression. Case et al. (2011) also indicated that the numerical results vary somewhat with different econometric specifications; thus, any numerical conclusion must be tentative.

8 Ludwig and Sløk (2004) also documented regression results using stock market capitalization data as a more direct measure of stock market wealth. We also employed stock market capitalization in one of our previous modelling attempts and found some similar results with the existing modeling.

9 The ECB (2009) recommended the use of price data instead of the stock of wealth (Dreger and Reimers 2012). 
Annual data on population are obtained from the World Bank. Notwithstanding the many studies in the literature that employ labour income as the mainstream variable to explain household consumption, we use the net real per capita national disposable income due to the unavailability of labour income data for the selected observation period. However, it should be noted that several studies in the literature have employed disposable income instead of labour income as an explanatory variable for consumption, such as Ludwig and Sløk (2004) and Dreger and Reimers (2012). ${ }^{10}$ Since data on consumption, share prices, and house prices are quarterly, whereas income and population series are annual, we use linear interpolation to acquire quarterly series on income and population. ${ }^{11}$ After dividing the consumption and income series by the interpolated population values, we obtain quarterly consumption per capita and income per capita variables, respectively. We use nominal short-term interest rates in line with the literature. ${ }^{12}$ Finally, we deflate all series except interest rates by the consumer price index and take their natural logarithm to build a log-log model, which allows us to calculate elasticities of income, housing wealth, and stock wealth. By comparing elasticities, we are able to decompose the housing and stock wealth effects on consumption. Table 1 presents the descriptive statistics.

Table 1. Descriptive Statistics.

\begin{tabular}{cccccc}
\hline Variables $^{*}$ & Obs & Mean & Std. Dev. & Min & Max \\
\hline Consumption & 1550 & $20,506.29$ & 6362.11 & 9770.37 & $40,528.9$ \\
Income & 1550 & $25,934.6$ & 6587.03 & $13,063.85$ & $43,359.53$ \\
Stock Market Index & 1550 & 68.16 & 50.51 & 1.54 & 310.32 \\
Housing Price Index & 1550 & 59.35 & 37.42 & 2.53 & 182.75 \\
Interest Rate & 1550 & 6.38 & 4.81 & -0.84 & 25.78 \\
\hline
\end{tabular}

* See Appendix A, for the full explanations of the variables.

\subsection{Modelling Strategies and Empirical Results}

\subsubsection{Empirical Specifications of the Consumption-Wealth Effect Nexus}

According to the life cycle (Modigliani and Brumberg 1954; Ando and Modigliani 1963) and permanent income (Friedman 1957) hypotheses, consumers form estimates of their ability to consume in the long run and then set their current consumption to the appropriate fraction of that estimate. The estimate may be stated in the form of wealth, following Modigliani, in which case the fraction is the annuity value of wealth, or as permanent income (Hall 1978). The life cycle model generates a common upward trend in aggregate consumption, labour income, and financial wealth (Gali 1990), whereas Friedman (1957) defined a relation between permanent income and permanent consumption. Apergis et al. (2014) indicated that the permanent income hypothesis provides the rationale that private consumption responds to changes in permanent income, including asset wealth and human wealth. While housing wealth and stock market wealth are the two major forms of asset wealth, human wealth ${ }^{13}$ is assumed to be determined essentially by labour income.

10 Dreger and Reimers (2012) reported that, in addition to labour income, disposable income includes income received from wealth, like interest payments, profits, and dividends. Consistent labour income measures are not available in an international setting, as effective wages are not reported for some countries. In other countries, they refer not to the entire economy but only to the industrial sector. Therefore, disposable income represents a broader income concept.

11 The literature on the determinants of household consumption includes many studies that employed interpolation methods to increase the frequency of the data. Accordingly, the interpolated variables include household consumption (Chen 2006; De Bandt et al. 2010), housing wealth (Rapach and Strauss 2006; Slacalek 2009), financial wealth (Floam 2005; Sousa 2010), population (Barrell et al. 2015), and income (Heinrichs 2016).

12 Taylor et al. (1971), Heien (1972), Mishkin (1976), Gylfason (1981), Wilcox (1990), Kerdrain (2011), and MacDonald et al. (2011), among others, also used nominal interest rates for their analysis on the relationship between consumption and interest rates.

13 As discussed by Bertaut (2002), estimating the long-run relationship between consumption, income, and wealth, households are assumed to follow a life cycle model and base their consumption on their overall stock of wealth, including human 
Following, among others, Ludwig and Sløk (2004), DeJuan et al. (2006), Apergis et al. (2014), and Jawadi et al. (2015), we define household consumption as a function of income, and wealth. We also additionally employ interest rates by following Hansen (1996), MacDonald et al. (2011), Kerdrain (2011), and Jaramillo and Chailloux (2015), among others. Therefore, we primarily aim to explore the components of consumption with a specific focus on the relationship between consumption and wealth effect with an extension of using interest rates as the additional variable.

Therefore, as also discussed in Section 2.1, we specify a long-run consumption function between consumption, income, interest rates, and the aggregated wealth components as follows: ${ }^{14}$

$$
C_{t}=f\left(c_{y} Y_{t}+c_{i} I_{t}+c_{w} W_{t}\right)
$$

In Equation (1), consumption is denoted as a linear function of income, interest rates, and wealth, in which $C_{t}$ is the household final consumption at time $t, Y_{t}$ is the household income, $I_{t}$ is the interest rates, $W_{t}$ is the total net worth of the household, and $c_{y}$, and $c_{w}$ are marginal propensities to consume over income and wealth, respectively. Additionally, $c_{i}$ is the interest rates elasticity of consumption. To gauge the effects of housing wealth and stock wealth separately, we extend the consumption function further to decompose household wealth into housing and stock wealth.

$$
C_{t}=f\left(c_{y} Y_{t}+c_{i} I_{t}+c_{s} S_{t}+c_{h} H_{t}\right)
$$

in which $S_{t}$ is the stock market wealth and $H_{t}$ is the housing wealth. $c_{s}$ and $c_{h}$ denote the marginal propensity to consume coefficients of stock wealth, and housing wealth, respectively. Equation (3) shows the log levels of the relevant variables.

$$
C_{\mathrm{I}, \mathrm{t}}=\alpha_{i}+\beta_{\mathrm{I}, \mathrm{y}} \mathrm{Y}_{\mathrm{I}, \mathrm{t}}+\beta_{\mathrm{I}, \mathrm{i}} I_{i, t}+\beta_{\mathrm{I}, \mathrm{sw}} S W_{i, t}+\beta_{\mathrm{I}, \mathrm{hw}} H W_{i, t}+\varepsilon_{\mathrm{I}, \mathrm{t}} \quad i=1,2, \ldots, N \text { and } t=1,2, \ldots, T,
$$

in which $C_{\mathrm{I}, \mathrm{t}}, \mathrm{Y}_{\mathrm{I}, \mathrm{t}}, S W_{i, t}$, and $H W_{i, t}$ are the log levels of consumption, income, stock wealth, and housing wealth in country I, respectively. $\varepsilon_{\mathrm{I}, \mathrm{t}}$ is the error term that captures the effects of unexpected shocks to consumption.

\subsubsection{Cross-Sectional Dependence Tests}

In panel data econometrics, cross-sectional dependence is an important issue. In the earlier studies, it was assumed that errors were cross-sectionally independent and slopes were homogeneous. However, with the emergence of micro panels in which both the time series $(T)$ and the cross-section $(N)$ dimensions are large, testing for cross-sectional dependence gained prominence.

Cross-correlated errors might be caused by several issues, such as omitted common effects, interactions within socioeconomic networks, and spatial effects (Chudik and Pesaran 2013). Overlooking cross-sectional dependence might generate unintended outcomes. First, conventional unit root tests have significant size distortions if the errors are cross-sectionally dependent (O'Connell 1998). Second, ignoring cross-sectional dependence by employing fixed- or random-effect methodologies is likely to create inconsistent and biased estimators (Sarafidis and Robertson 2009).

The cross-sectional dependence of errors is tested by employing the $C D$ test proposed by Pesaran (2004). The $C D$ test is used when the cross-sectional dimension is greater than the time dimension in the panel $(N>T)$. The test is robust to structural breaks, as well as non-normality of errors. However, it might be inconsistent if the cross-sectional dimension is smaller than the time

capital wealth and financial and non-financial wealth. To estimate the model, it is assumed that human capital wealth is proportional to the current labour income, so the empirical specification estimates consumption as a function of the current income and current wealth.

14 As suggested by Ludvigson and Steindel (1999), derivations of such equations from the underlying theory of consumer behaviour may be found in the studies by Modigliani and Tarantelli (1975), Modigliani et al. (1977), and Steindel (1981). 
dimension in the panel $(N<T)$. The bias-adjusted $L M$ test proposed by Pesaran et al. (2008) solves the inconsistency issue. In this study, we use both tests to check whether cross-sectional dependence exists in our data.

The $C D$ test statistic is calculated as follows:

$$
C D=\sqrt{\frac{2 T}{N(N-1)}}\left(\sum_{i=1}^{N-1} \sum_{j=i+1}^{N} \hat{\rho}_{i j}\right) \sim N(0,1) i, j=1,2,3, \ldots, N
$$

and the bias-adjusted version of the $C D$ test is

$$
L M^{*}=\sqrt{\frac{2 T}{N(N-1)}}\left(\sum_{i=1}^{N-1} \sum_{j=i+1}^{N} \hat{\rho}_{i j}\right) \frac{(T-k) \hat{\rho}_{i j}{ }^{2}-E(T-k) \hat{\rho}_{i j}{ }^{2}}{\operatorname{Var}(T-k) \hat{\rho}_{i j}{ }^{2}},
$$

in which $\hat{\rho}_{i j}$ is the sample estimate of the pairwise correlation of the residuals obtained by OLS (Hernández-Salmarón and Romero-Ávila 2015).

Table 2 exhibits the results of the $C D$ and bias-adjusted $L M$ tests. Accordingly, the null hypothesis of no cross-sectional dependence is rejected, which indicates that we should use methods that are robust to cross-sectional dependence to avoid inconsistent and biased results.

Table 2. Cross-sectional Dependence Test Results.

\begin{tabular}{cc}
\hline & Value \\
\hline CD Test & $16.3^{* * *}$ \\
Bias Adjusted LM Test & $445.7^{* * *}$ \\
\hline
\end{tabular}

$*, * *, * * *$ indicate that statistics are significant at the $10 \%, 5 \%$, and $1 \%$ level of significance, respectively. The null hypothesis is no cross-sectional dependence.

\subsubsection{Unit Root and Cointegration Tests}

After detecting cross-sectional dependence in the data, we employ the CIPS panel unit root test (Pesaran 2007), which is robust to cross-sectional dependence. The CIPS test uses the following augmented Dickey-Fuller regression to calculate the cross-sectionally augmented ADF statistic (CADF).

$$
\Delta y_{i, t}=a_{i}+b_{i} y_{i, t-1}+c_{i} \bar{y}_{t-1}+d_{i} \Delta \bar{y}_{t}+\varepsilon_{i t},
$$

in which $\bar{y}_{t}=\frac{1}{N} \sum_{i=1}^{N} y_{i, t}, \Delta \bar{y}_{t}=\frac{1}{N} \sum_{i=1}^{N} \Delta y_{i, t}$, and $\varepsilon_{i t}$ is the error term. Then, using the CADF statistic calculated above, the CIPS statistic is derived as shown in Equation (7).

$$
\text { CIPS }=\frac{1}{N} \sum_{i=1}^{N} C A D F_{i}
$$

The results of the CIPS unit root test are exhibited in Table 3. Since the null hypothesis of a unit root could not be rejected, we conclude that all the variables are non-stationary in levels. 
Table 3. CIPS Unit Root Test Results.

\begin{tabular}{ccc}
\hline & \multicolumn{2}{c}{ CIPS } \\
\cline { 2 - 3 } & Intercept & Intercept + Trend \\
\hline Consumption & -1.144 & 2.194 \\
Income & -1.219 & 1.131 \\
Stock Wealth & -0.412 & 0.725 \\
Housing Wealth & 0.734 & 1.669 \\
Interest Rate & -0.968 & -1.008
\end{tabular}

$*, * *, * * *$ indicate that statistics are significant at the $10 \%, 5 \%$, and $1 \%$ level of significance, respectively. For the CIPS test the null hypothesis is nonstationarity.

After concluding that all the series are I(1), we investigate whether the series are cointegrated. Cointegration enables us to employ non-stationary variables in levels without creating a spurious relationship if a linear combination of them is integrated with order zero (Atasoy 2017). In this respect, we employ the second-generation Durbin-Hausman test advanced by Westerlund (2008), which takes cross-sectional dependence into account. The Durbin-Hausman test generates two test statistics. The panel test (DHp) assumes that the autoregressive parameter is the same for all the cross-sections. Rejection of the null hypothesis implies cointegration for all the cross-sections. The group test ( $\mathrm{DHg})$ permits the autoregressive parameter to differ across cross-sections. Similar to the DHg, if the null hypothesis is rejected, one concludes that cointegration exists. The results of the Durbin-Hausman test are presented in Table 4. Since both the DHg and the DHp test reject the null hypothesis of no cointegration, we conclude that the series are cointegrated. In other words, the results suggest that consumption has a long-term relation with income, stock wealth, housing wealth, and interest rates.

Table 4. Durbin-Hausman Cointegration Test Results.

\begin{tabular}{|c|c|}
\hline & Value \\
\hline & DHg $4.27^{* * *}$ \\
\hline & DHp $5.52^{* * *}$ \\
\hline
\end{tabular}

\subsubsection{Slope Heterogeneity Test}

Due to improvements in data availability, panels with large cross-section and time dimensions have started to be seen more often. Nevertheless, the asymptotics of large $N$, large $T$ panels are different from the asymptotics of traditional large $N$, small $T$ panels (Blackburne and Frank 2007). Assuming slope homogeneity and using pooling of individual groups allow only the intercepts to differ across the groups, and one may employ fixed-effect, random-effect, and instrumental variable estimators. However, if homogeneous slope assumption is not valid, the traditional estimators will be biased. In most panels with a large $N$ and $T$, the slope is heterogeneous (Pesaran and Smith 1995; Im et al. 2003).

To test for slope heterogeneity, we perform the slope heterogeneity test proposed by Pesaran and Yamagata (2008), which takes the presence of cross-sectional dependence into account. The test introduces a rescaled version of the Swamy test (Swamy 1970) and has superior size and power properties over a variety of specifications of $N$ and $T$ (Juhl and Lugovskyy 2014).

The results of the slope heterogeneity tests are presented in Table 5. As can be seen from the table, all the test statistics are above the critical value, indicating that we should reject the null hypothesis of slope homogeneity. Thus, since the slope is heterogeneous, we employ an estimator that allows for slope heterogeneity. 
Table 5. Slope Heterogeneity Test Results.

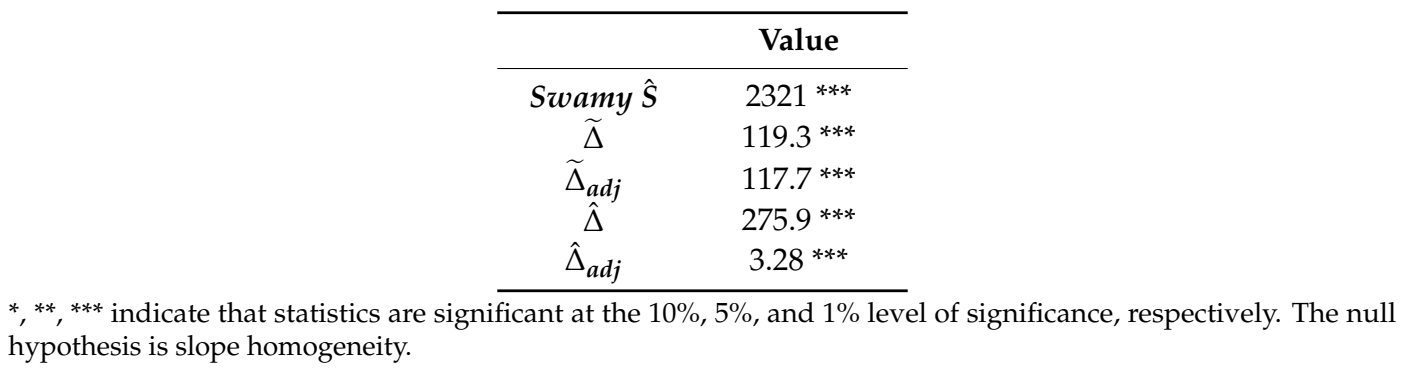

\subsubsection{Common Correlated Effects Mean Group Estimation}

Since our data are cross-sectionally dependent and heterogeneously sloped and the literature indicates that consumption might be endogenous (Davis and Palumbo 2001; Mehra 2001; Campbell and Cocco 2007), we use the common correlated effects mean group estimator (CCEMG), first proposed by Pesaran (2006) and improved by Kapetanios et al. (2011), which is robust to slope heterogeneity, endogeneity, and cross-sectional dependence. It should be noted that the CCEMG estimator is also robust to structural breaks and non-stationary unobserved common factors. In this respect, both two-stage least-squares (2SLS) and generalized method of moments (GMM) methodologies are also used.

The CCEMG estimator employs the methodology stated in Equation (8):

$$
y_{i t}=\alpha_{1 i}+\beta_{i} x_{i t}+\delta_{i} \bar{y}_{i t}+\theta_{i} \bar{x}_{i t}+\varphi_{i} f_{t}+\varepsilon_{i t}
$$

in which $y_{i t}$ is the dependent variable, $\alpha_{1 i}$ is the group fixed effects capturing the time-invariant heterogeneity across groups, $x_{i t}$ is the vector of regressors, $\bar{x}_{i t}$ and $\bar{y}_{i t}$ are the cross-sectional averages, $\beta_{i}$ represents the country-specific slope on the observable regressor, $\delta_{i}$ and $\theta_{i}$ are the coefficients of the cross-sectional averages of $\bar{x}_{i t}$ and $\bar{y}_{i t}, f_{t}$ is the unobserved common factor with heterogeneous factor loadings $\varphi_{i}$, and $\varepsilon_{i t}$ denotes the error term.

Equation (8) is estimated by OLS for each cross-section, and Newey and West (1987) estimators are used to take heteroskedasticity and autocorrelation into account. As shown in Equation (9), the mean group estimator for the CCE is derived by taking the average of each coefficient over each individual regression as follows:

$$
C C E M G=N^{-1} \sum_{i=1}^{N} \hat{\beta}_{i}
$$

in which $\hat{\beta}_{i}$ are the estimates of the coefficients in Equation (8). Whole-panel and country-specific CCEMG estimator results are, respectively, reported in Tables 7 and 8 in Section 4.1 to discuss broadly the evidence and its implications. The country-specific 2SLS and GMM estimator results are, respectively, in Tables 9 and 10 in Section 4.1.

\subsubsection{Causality Test}

The results of the CCEMG estimators provide invaluable evidence regarding stock and housing wealth effects on household consumption. However, these results lack information on the causal relationship between our variables of interest. To complement our findings, we employ the Granger causality test introduced by Dumitrescu and Hurlin (2012), which is robust to cross-sectional dependence and parameter heterogeneity. The test involves running Granger non-causality tests for each cross-section individually. 
The Dumitrescu-Hurlin test involves the following model:

$$
y_{i, t}=\alpha_{i}+\sum_{k=1}^{K} \beta_{i k} y_{i, t-k}+\sum_{k=1}^{K} \gamma_{i k} x_{i, t-k}+\varepsilon_{i, t}
$$

in which $y_{i, t}$ and $x_{i, t}$ are the variables of interest, $\alpha_{i}$ is the constant, $k$ is the lag order, and $\varepsilon_{i, t}$ is the error term. Granger (1969), the Dumitrescu-Hurlin panel causality test assumes the absence of causality for all the individuals in the panel and defines the null hypothesis as follows:

$$
H_{0}=\gamma_{i 1}=\gamma_{i 2}=\ldots=\gamma_{i k}=0 \forall_{i}=1,2, \ldots, N .
$$

The alternative hypothesis asserts that there is at least one Granger causal relationship in the panel:

$$
\begin{gathered}
H_{1}=\gamma_{i 1}=\gamma_{i 2}=\ldots=\gamma_{i k}=0 \quad \forall_{i}=1,2, \ldots, N_{1} \\
\gamma_{i 1} \neq 0 \text { or } \gamma_{i 2} \neq 0 \text { or } \ldots=\gamma_{i k}=0 \quad \forall_{i}=N_{1}+1,2, \ldots, N,
\end{gathered}
$$

in which $N_{1} \in[0, N-1]$.

The Dumitrescu-Hurlin test generates the Wald statistic $(W)$ to test the null hypothesis and then calculates the $\bar{W}$ statistic by taking the average of $\mathrm{N}$ individual Wald statistics.

$$
\bar{W}=\frac{1}{N} \sum_{i=1}^{N} W_{i}
$$

Assuming that the Wald statistics are independently and identically distributed across individuals, the standardized $\bar{Z}$ and $\widetilde{Z}$ Wald statistics can be calculated as follows:

$$
\begin{gathered}
\bar{Z}=\sqrt{\frac{N}{2 K}}(\bar{W}-K) \\
\widetilde{Z}=\sqrt{\frac{N}{2 K}\left(\frac{T-3 K-5}{T-2 K-3}\right)}\left(\frac{T-3 K-3}{T-3 K-1}\right)(\bar{W}-K)
\end{gathered}
$$

in which $T$ is the number of periods, $N$ is the number of cross-sections, and $K$ is the number of lags. If the calculated $\bar{Z}$ and $\widetilde{Z}$ Wald statistics are larger than the critical values, then the null hypothesis is rejected, indicating causality between series. ${ }^{15}$ Accordingly, Table 6 suggests the existence of bidirectional causality between the pairs of consumption-income, consumption-stock wealth, and consumption-housing wealth. The results also show bidirectional causalities between income and housing wealth, interest rate and consumption, and interest rate and income. Moreover, the results suggest unidirectional causalities from stock wealth to income, from stock wealth to housing wealth, from interest rate to stock wealth, and from interest rate to housing wealth.

15 For panels with a large $N$ and $T ; \bar{W}$ should be preferred. For panels with a large $N$ and small $T$, one could use $\widetilde{Z}$. 
Table 6. Dumitrescu-Hurlin Panel Causality Test Results.

\begin{tabular}{|c|c|c|c|}
\hline Directon of Causality & Z_bar & Z_bar_tilde & Result \\
\hline Income $\longrightarrow$ Consumption & $3.9772 * * *$ & $3.7294 * *$ & \multirow{2}{*}{ Bidirectional Causality } \\
\hline Consumption $\longrightarrow$ Income & $8.2897^{* * *}$ & $6.7406^{* * *}$ & \\
\hline Housing Wealth $\longrightarrow$ Consumption & $5.6692 * * *$ & $5.5090^{* * *}$ & \multirow{2}{*}{ Bidirectional Causality } \\
\hline Consumption $\longrightarrow$ Housing Wealth & $6.8472^{* * *}$ & $6.6603^{* * *}$ & \\
\hline Stock Wealth $\longrightarrow$ Consumption & $5.4192 * * *$ & $5.2646^{* * *}$ & \multirow{2}{*}{ Bidirectional Causality } \\
\hline Consumption $\longrightarrow$ Stock Wealth & $5.0022 * * *$ & $4.8823 * * *$ & \\
\hline Income $\longrightarrow$ Stock Wealth & $1.6873 *$ & 1.6041 & \multirow{2}{*}{$\begin{array}{l}\text { Unidirectional Causality from } \\
\text { stock wealth to income }\end{array}$} \\
\hline Stock Wealth $\longrightarrow$ Income & $10.2517^{* * *}$ & $9.9876^{* * *}$ & \\
\hline Housing Wealth $\longrightarrow$ Stock Wealth & 1.3066 & 1.2333 & \multirow{2}{*}{$\begin{array}{l}\text { Unidirectional Causality from } \\
\text { stock wealth to housing wealth }\end{array}$} \\
\hline Stock Wealth $\longrightarrow$ Housing Wealth & $4.3158^{* * *}$ & $4.1647^{* * *}$ & \\
\hline Income $\longrightarrow$ Housing Wealth & $7.5912 * * *$ & $7.3237^{* * *}$ & \multirow{2}{*}{ Bidirectional Causality } \\
\hline Housing Wealth $\longrightarrow$ Income & $5.3883^{* * *}$ & $5.0158^{* * *}$ & \\
\hline Interest Rate $\longrightarrow$ Consumption & $4.6836^{* * *}$ & $4.5410^{* * *}$ & \multirow{2}{*}{ Bidirectional Causality } \\
\hline Consumption $\longrightarrow$ Interest Rate & $5.3970 * * *$ & $5.2662 * * *$ & \\
\hline Interest Rate $\longrightarrow$ Income & $5.8872 * * *$ & $5.7469^{* * *}$ & \multirow{2}{*}{ Bidirectional Causality } \\
\hline Income $\longrightarrow$ Interest Rate & $5.6274^{* * *}$ & $5.2158^{* * *}$ & \\
\hline Interest Rate $\longrightarrow$ Stock Wealth & $9.2031^{* * *}$ & $8.8825^{* * *}$ & \multirow{2}{*}{$\begin{array}{l}\text { Unidirectional Causality from } \\
\text { interest rate to stock wealth }\end{array}$} \\
\hline Stock Wealth $\longrightarrow$ Interest Rate & 1.4021 & 1.2158 & \\
\hline Interest Rate $\longrightarrow$ Housing Wealth & $5.8997^{* * *}$ & $5.7025^{* * *}$ & \multirow{2}{*}{$\begin{array}{l}\text { Unidirectional Causality from } \\
\text { interest rate to housing wealth }\end{array}$} \\
\hline Housing Wealth $\longrightarrow$ Interest Rate & 1.2698 & 1.1843 & \\
\hline
\end{tabular}

\section{Whole-Panel and Country-Level Empirical Results and Implications}

\subsection{Whole-Panel and Country-Level Empirical Results}

The results of the CCEMG estimations for the whole panel are depicted in Table 7. The second column exhibits the results of the baseline CCEMG specification, whereas the third and fourth columns present the results of the endogeneity-robust 2SLS and GMM specifications, respectively. The detailed evidence of the country-level analyses and their implications are discussed in Section 4.2. As expected, income is the largest component of household final consumption, with a coefficient value around $0.52-0.54$ in three specifications. This implies that a 1 per cent increase in the net real per capita national disposable income (income) causes a $0.52-0.54$ per cent increase in household real per capita final consumption expenditure (consumption). Housing wealth has elasticity of around 0.14 in all specifications, which is essentially in-line with the literature. This outcome implies that house prices and consumption are positively correlated, and that a 1 per cent increase in housing wealth proxied by house price index causes a 0.14 per cent increase in consumption. However, the evidence for the whole panel also suggests counter-intuitive results. In this respect, stock wealth and consumption have negative, and interest rate and consumption have positive, relations with insignificant coefficient values in all three specifications. However, below country level results suggest some consistent evidences with common intuition. 
Table 7. CCEMG Estimator Results.

\begin{tabular}{cccc}
\hline & CCE & CCE-2SLS & CCE-GMM \\
\hline Income & $0.537^{* * *}$ & $0.521^{* * *}$ & $0.529 * * *$ \\
& $(0.0826)$ & $(0.0866)$ & $(0.0834)$ \\
\hline Stock Market Wealth & -0.00391 & -0.00220 & -0.00279 \\
& $(0.0131)$ & $(0.0136)$ & $(0.0132)$ \\
\hline Housing Wealth & $0.139^{* * *}$ & $0.142^{* * *}$ & $0.140 * * *$ \\
& $(0.0206)$ & $(0.0221)$ & $(0.0240)$ \\
\hline Interest Rates & 0.00018 & 0.000079 & 0.000025 \\
& $(0.00085)$ & $(0.0008)$ & $(0.00085)$ \\
\hline Constant & 0.467 & 0.450 & 0.477 \\
& $(0.661)$ & $(0.648)$ & $(0.685)$ \\
\hline$N$ & 1550 & 1528 & 1528 \\
\hline
\end{tabular}

HAC standard errors in parentheses. ${ }^{*} p<0.10,{ }^{* *} p<0.05,{ }^{* * *} p<0.01$.

Using the convenience of the CCEMG estimator, we also present the results for 11 countries separately in Table 8 . Accordingly, the elasticity of income lies between 0.50 and 0.85 . While the income elasticity for consumption is found to be fairly large in Italy (0.85) and Japan (0.80), Finland (0.50) and UK (0.56) appear to have the lowest elasticity. The country-level results suggest interesting patterns of the linkages between consumption, interest rates, and stock and housing wealth effects in Tables 8-10.

Reflecting the results of our baseline model, Table 8 implies that the housing wealth effect is positive and statistically significant for all the countries. Among these countries, Japan has the lowest (0.09) and Switzerland has the highest housing wealth effect (0.19). On the other hand, the evidence is mixed for the stock wealth effect. Stock markets generally show small wealth effects on consumption either positively or negatively. Accordingly, the stock wealth effect is negative in five countries and positive in two countries with significant coefficient values. In this respect, the evidence suggests that, while stock market wealth has negative impacts on consumption in Australia (-0.08), Finland $(-0.05)$, Italy $(-0.02)$, Japan $(-0.07)$, and the US $(-0.03)$, it has positive impacts in Canada $(0.06)$ and Switzerland (0.06). The results also suggest that the impact of housing wealth on consumption is greater than the impact of stock wealth, in line with several studies discussed in Sections 2.2 and 4.2. Additionally, interest rates generally show insignificant effect on consumption. In this respect, while interest rate has negative effect on consumption in Australia, Italy, New Zealand, and the US with coefficient values between 0.0014 and 0.0033 , the relationship is positive in the cases of France, Switzerland, and UK.

As a robustness check, we also use endogeneity-robust 2SLS and GMM estimators in Tables 9 and 10, respectively. No significant change is generally observed in the housing wealth effect. Interestingly, the evidence suggests a negative and statistically significant relationship between stock wealth and consumption for the US (Table 9) with a coefficient of -0.03 . Tables 8-10 collectively suggest that all the countries have positive housing wealth effects in all the specifications. Housing wealth effect becomes stronger for some countries in Tables 9 and 10. Interestingly, the UK is the largest housing wealth effects in Tables 9 and 10. In addition to UK and some other countries, the evidence also suggests a higher housing wealth effect for US in Tables 9 and 10. The evidence further suggests in different specifications that the housing wealth effect is generally weak in Australia, Finland, and Japan. 
Table 8. Country-Specific Results of the CCEMG Estimator.

\begin{tabular}{|c|c|c|c|c|c|c|c|c|c|c|c|}
\hline & Australia & Canada & Finland & France & Italy & Japan & N. Zealand & Sweden & Switzerland & UK & US \\
\hline Income & $\begin{array}{l}0.627^{* * *} \\
(0.0389)\end{array}$ & $\begin{array}{c}0.7169^{* * *} \\
(0.0312)\end{array}$ & $\begin{array}{c}0.5014 \text { *** } \\
(0.0587)\end{array}$ & $\begin{array}{c}0.6084^{* * *} \\
(0.0272)\end{array}$ & $\begin{array}{c}0.8548^{* * *} \\
(0.0302)\end{array}$ & $\begin{array}{c}0.8017^{* * *} \\
(0.0204)\end{array}$ & $\begin{array}{l}0.683^{* * *} \\
(0.0338)\end{array}$ & $\begin{array}{c}0.7177^{* * *} \\
(0.0325)\end{array}$ & $\begin{array}{c}0.6692^{* * *} \\
(0.0336)\end{array}$ & $\begin{array}{c}0.5614^{* * *} \\
(0.0579)\end{array}$ & $\begin{array}{c}0.723 * * * \\
(0.014)\end{array}$ \\
\hline $\begin{array}{r}\text { Stock } \\
\text { Wealth }\end{array}$ & $\begin{array}{c}-0.0807^{* * *} \\
(0.0157)\end{array}$ & $\begin{array}{c}0.0627^{* * *} \\
(0.0082)\end{array}$ & $\begin{array}{c}-0.0459 * * * \\
(0.0075)\end{array}$ & $\begin{array}{c}0.0109 \\
(0.0098)\end{array}$ & $\begin{array}{c}-0.0156 \text { * } \\
(0.0083)\end{array}$ & $\begin{array}{c}-0.068^{* * * *} \\
(0.0059)\end{array}$ & $\begin{array}{l}-0.0131 \\
(0.0085)\end{array}$ & $\begin{array}{l}0.0305 \\
(0.019) \\
\end{array}$ & $\begin{array}{c}0.0595^{* * *} \\
(0.0103)\end{array}$ & $\begin{array}{l}-0.0223 \\
(0.0289)\end{array}$ & $\begin{array}{c}-0.0303^{* * *} \\
(0.0057)\end{array}$ \\
\hline $\begin{array}{l}\text { Housing } \\
\text { Wealth }\end{array}$ & $\begin{array}{c}0.0964^{* * *} \\
(0.033)\end{array}$ & $\begin{array}{c}0.1514^{* * *} \\
(0.0152)\end{array}$ & $\begin{array}{c}0.0914^{* * *} \\
(0.0194)\end{array}$ & $\begin{array}{c}0.1357^{* * *} \\
(0.0193)\end{array}$ & $\begin{array}{l}0.137 * * * \\
(0.0159)\end{array}$ & $\begin{array}{c}0.0912 * * * \\
(0.0111)\end{array}$ & $\begin{array}{c}0.1838 * * * \\
(0.0176)\end{array}$ & $\begin{array}{c}0.1752^{* * *} \\
(0.035)\end{array}$ & $\begin{array}{c}0.1901^{* * *} \\
(0.0229)\end{array}$ & $\begin{array}{c}0.1558^{* * *} \\
(0.0224)\end{array}$ & $\begin{array}{c}0.1183^{* * *} \\
(0.0099)\end{array}$ \\
\hline $\begin{array}{c}\text { Interest } \\
\text { Rate }\end{array}$ & $\begin{array}{c}-0.0024^{* * *} \\
(0.0008)\end{array}$ & $\begin{array}{c}0.0009 \\
(0.0008)\end{array}$ & $\begin{array}{l}-0.0016 \\
(0.0015)\end{array}$ & $\begin{array}{c}0.0032 * * * \\
(0.0008)\end{array}$ & $\begin{array}{c}-0.0033^{* * *} \\
(0.0013)\end{array}$ & $\begin{array}{c}0.0027 \\
(0.0103)\end{array}$ & $\begin{array}{c}-0.0014^{* *} \\
(0.0006)\end{array}$ & $\begin{array}{l}-0.0003 \\
(0.0019)\end{array}$ & $\begin{array}{c}0.0036^{* * *} \\
(0.001)\end{array}$ & $\begin{array}{c}0.0039 * * * \\
(0.0015)\end{array}$ & $\begin{array}{c}-0.0033^{* * *} \\
(0.0004)\end{array}$ \\
\hline Constant & $\begin{array}{l}-0.0732 \\
(0.1339)\end{array}$ & $\begin{array}{c}0.2299 * * \\
(0.0967)\end{array}$ & $\begin{array}{l}-0.3904 \\
(0.3269)\end{array}$ & $\begin{array}{l}-0.0703 \\
(0.0934)\end{array}$ & $\begin{array}{c}-0.6771^{* * *} \\
(0.0849)\end{array}$ & $\begin{array}{c}0.0889 \\
(0.1041)\end{array}$ & $\begin{array}{c}-1.6931^{* * *} \\
(0.1567)\end{array}$ & $\begin{array}{c}-1.2725^{*} \\
(0.5952)\end{array}$ & $\begin{array}{c}0.1306 \\
(0.1926)\end{array}$ & $\begin{array}{c}2.2922 * * * \\
(0.4292)\end{array}$ & $\begin{array}{c}0.3367^{* * * *} \\
(0.0622)\end{array}$ \\
\hline
\end{tabular}

HAC standard errors in parentheses. ${ }^{*} p<0.10,{ }^{* *} p<0.05,{ }^{* * *} p<0.01$.

Table 9. Country-specific Results of the CCEMG-2SLS Estimator.

\begin{tabular}{|c|c|c|c|c|c|c|c|c|c|c|c|}
\hline & Australia & Canada & Finland & France & Italy & Japan & $\begin{array}{c}\text { New } \\
\text { Zealand }\end{array}$ & Sweden & Switzerland & UK & US \\
\hline Income & $\begin{array}{c}0.6157^{* * *} \\
(0.0386)\end{array}$ & $\begin{array}{c}0.6921^{* * *} \\
(0.0305)\end{array}$ & $\begin{array}{c}0.4888^{* * *} \\
(0.0576)\end{array}$ & $\begin{array}{c}0.6202 \text { *** } \\
(0.0273)\end{array}$ & $\begin{array}{c}0.8526^{* * *} \\
(0.032)\end{array}$ & $\begin{array}{c}0.8002 * * * \\
(0.0681)\end{array}$ & $\begin{array}{c}0.6754^{* * *} \\
(0.0334)\end{array}$ & $\begin{array}{c}0.6932 \text { *** } \\
(0.0202)\end{array}$ & $\begin{array}{c}0.7369 * * * \\
(0.0344)\end{array}$ & $\begin{array}{c}0.5243 * * * \\
(0.061)\end{array}$ & $\begin{array}{c}0.7154^{* * * *} \\
(0.014)\end{array}$ \\
\hline $\begin{array}{r}\text { Stock } \\
\text { Wealth }\end{array}$ & $\begin{array}{c}-0.0769^{* * *} \\
(0.0155)\end{array}$ & $\begin{array}{c}0.0666^{* * *} \\
(0.0079)\end{array}$ & $\begin{array}{c}-0.0457^{* * * *} \\
(0.0072)\end{array}$ & $\begin{array}{c}0.0055 \\
(0.0099)\end{array}$ & $\begin{array}{c}-0.0153 * \\
(0.0092)\end{array}$ & $\begin{array}{c}-0.0652 * * * \\
(0.0071)\end{array}$ & $\begin{array}{l}-0.0127 \\
(0.0082)\end{array}$ & $\begin{array}{c}0.0415 \text { *** } \\
(0.0161)\end{array}$ & $\begin{array}{c}0.0661^{* * *} \\
(0.0093)\end{array}$ & $\begin{array}{l}-0.0242 \\
(0.0283)\end{array}$ & $\begin{array}{c}-0.0307^{* * * *} \\
(0.0056)\end{array}$ \\
\hline $\begin{array}{l}\text { Housing } \\
\text { Wealth }\end{array}$ & $\begin{array}{l}0.105^{* * *} \\
(0.0326)\end{array}$ & $\begin{array}{c}0.1488^{* * *} \\
(0.0144)\end{array}$ & $\begin{array}{c}0.0925^{* * *} \\
(0.0185)\end{array}$ & $\begin{array}{c}0.1265^{* * * *} \\
(0.0187)\end{array}$ & $\begin{array}{c}0.1372^{* * *} \\
(0.0154)\end{array}$ & $\begin{array}{c}0.0885^{* * *} \\
(0.0123)\end{array}$ & $\begin{array}{c}0.1857^{* * *} \\
(0.0171)\end{array}$ & $\begin{array}{c}0.1454^{* * *} \\
(0.0296)\end{array}$ & $\begin{array}{c}0.1412^{* * *} \\
(0.0101)\end{array}$ & $\begin{array}{c}0.2649^{* * *} \\
(0.0326)\end{array}$ & $\begin{array}{c}0.1205^{* * * *} \\
(0.0096)\end{array}$ \\
\hline $\begin{array}{c}\text { Interest } \\
\text { Rate }\end{array}$ & $\begin{array}{c}-0.0026^{* * *} \\
(0.0008)\end{array}$ & $\begin{array}{c}0.001 \\
(0.0007)\end{array}$ & $\begin{array}{l}-0.0018 \\
(0.0015)\end{array}$ & $\begin{array}{c}0.0037^{* * * *} \\
(0.0008)\end{array}$ & $\begin{array}{c}-0.0033^{* * * *} \\
(0.0013)\end{array}$ & $\begin{array}{c}0.0022 \\
(0.0092)\end{array}$ & $\begin{array}{c}-0.0015^{* * * *} \\
(0.0006)\end{array}$ & $\begin{array}{c}0.001 \\
(0.0016)\end{array}$ & $\begin{array}{c}0.0024^{* * *} \\
(0.0009)\end{array}$ & $\begin{array}{c}0.003 * \\
(0.0016)\end{array}$ & $\begin{array}{c}-0.0033^{* * *} \\
(0.0004)\end{array}$ \\
\hline Constant & $\begin{array}{l}-0.0708 \\
(0.1304)\end{array}$ & $\begin{array}{c}0.3006^{* * *} \\
(0.0937)\end{array}$ & $\begin{array}{l}-0.4439 \\
(0.3168)\end{array}$ & $\begin{array}{l}-0.1366 \\
(0.0934)\end{array}$ & $\begin{array}{c}-0.6717^{* * * *} \\
(0.0921)\end{array}$ & $\begin{array}{c}0.6398^{* * *} \\
(0.0244)\end{array}$ & $\begin{array}{l}-1.7198 \\
(0.1536)\end{array}$ & $\begin{array}{l}-0.7506 \\
(0.5096)\end{array}$ & $\begin{array}{c}-0.312 \\
(0.2034)\end{array}$ & $\begin{array}{c}0.9258^{* * *} \\
(0.0128)\end{array}$ & $\begin{array}{l}0.373^{* * *} \\
(0.0648)\end{array}$ \\
\hline
\end{tabular}

HAC standard errors in parentheses. ${ }^{*} p<0.10,{ }^{* *} p<0.05,{ }^{* * *} p<0.01$. 
Table 10. Country-Specific Results of the CCEMG-GMM Estimator.

\begin{tabular}{|c|c|c|c|c|c|c|c|c|c|c|c|}
\hline & Australia & Canada & Finland & France & Italy & Japan & $\begin{array}{c}\text { New } \\
\text { Zealand }\end{array}$ & Sweden & Switzerland & UK & US \\
\hline Income & $\begin{array}{c}0.6034^{* * *} \\
(0.074)\end{array}$ & $\begin{array}{c}0.701 * * * \\
(0.034)\end{array}$ & $\begin{array}{c}0.5027^{* * *} \\
(0.0888)\end{array}$ & $\begin{array}{c}0.6281^{* * *} \\
(0.0387)\end{array}$ & $\begin{array}{c}0.854^{* * *} \\
(0.0273)\end{array}$ & $\begin{array}{c}0.7363^{* * *} \\
(0.0298)\end{array}$ & $\begin{array}{c}0.6633^{* * *} \\
(0.0512)\end{array}$ & $\begin{array}{c}0.7458^{* * *} \\
(0.0429)\end{array}$ & $\begin{array}{c}0.6932 * * * \\
(0.0331)\end{array}$ & $\begin{array}{c}0.5225^{* * *} \\
(0.0633)\end{array}$ & $\begin{array}{c}0.7225 * * * \\
(0.0276)\end{array}$ \\
\hline $\begin{array}{c}\text { Stock } \\
\text { Wealth }\end{array}$ & $\begin{array}{c}-0.0763^{* * *} \\
(0.0307)\end{array}$ & $\begin{array}{c}0.0635^{* * *} \\
(0.0163)\end{array}$ & $\begin{array}{c}-0.0446^{* * *} \\
(0.0082)\end{array}$ & $\begin{array}{c}0.0031 \\
(0.0194) \\
\end{array}$ & $\begin{array}{c}-0.0186^{* * *} \\
(0.007)\end{array}$ & $\begin{array}{c}-0.0642^{* * *} \\
(0.0036)\end{array}$ & $\begin{array}{c}-0.0181 \text { ** } \\
(0.0076)\end{array}$ & $\begin{array}{c}0.0329 * * \\
(0.0149)\end{array}$ & $\begin{array}{c}0.0669 * * * \\
(0.0041)\end{array}$ & $\begin{array}{l}-0.0067 \\
(0.0323)\end{array}$ & $\begin{array}{c}-0.0317 \\
(0.065)\end{array}$ \\
\hline $\begin{array}{l}\text { Housing } \\
\text { Wealth }\end{array}$ & $\begin{array}{l}0.0851 \text { * } \\
(0.0515)\end{array}$ & $\begin{array}{c}0.1638^{* * *} \\
(0.0325)\end{array}$ & $\begin{array}{c}0.0899 * * * \\
(0.0308)\end{array}$ & $\begin{array}{c}0.1376^{* * *} \\
(0.0327)\end{array}$ & $\begin{array}{c}0.1473^{* * *} \\
(0.0241)\end{array}$ & $\begin{array}{c}0.1028^{* * *} \\
(0.0202)\end{array}$ & $\begin{array}{c}0.191 \text { *** } \\
(0.033)\end{array}$ & $\begin{array}{c}0.1511^{* * *} \\
(0.0173)\end{array}$ & $\begin{array}{c}0.192 * * * \\
(0.0112)\end{array}$ & $\begin{array}{c}0.2061^{* * *} \\
(0.0274)\end{array}$ & $\begin{array}{c}0.1215^{* * * *} \\
(0.0162)\end{array}$ \\
\hline $\begin{array}{c}\text { Interest } \\
\text { Rate }\end{array}$ & $\begin{array}{l}-0.0025 \\
(0.0019)\end{array}$ & $\begin{array}{c}0.0007 \\
(0.0012)\end{array}$ & $\begin{array}{l}-0.0014 \\
(0.0023)\end{array}$ & $\begin{array}{c}0.0034^{* *} \\
(0.0017)\end{array}$ & $\begin{array}{l}-0.0042 \\
(0.0027)\end{array}$ & $\begin{array}{c}0.0048 \\
(0.0054)\end{array}$ & $\begin{array}{c}-0.0014^{* * *} \\
(0.0005)\end{array}$ & $\begin{array}{c}0.0008 \\
(0.0015)\end{array}$ & $\begin{array}{c}0.0027^{* * *} \\
(0.0007)\end{array}$ & $\begin{array}{c}0.0009 \\
(0.0028)\end{array}$ & $\begin{array}{c}-0.0033^{* * *} \\
(0.0006)\end{array}$ \\
\hline Constant & $\begin{array}{c}-0.1214 \\
(0.229)\end{array}$ & $\begin{array}{c}0.2794 \\
(0.2205)\end{array}$ & $\begin{array}{c}-0.385 \\
(0.3954)\end{array}$ & $\begin{array}{l}-0.1296 \\
(0.1304)\end{array}$ & $\begin{array}{c}-0.712^{* * *} \\
(0.1285)\end{array}$ & $\begin{array}{c}0.2278 \\
(0.1856)\end{array}$ & $\begin{array}{c}-1.783^{* * *} \\
(0.2121)\end{array}$ & $\begin{array}{l}-0.4966 \\
(0.5043)\end{array}$ & $\begin{array}{l}-0.2033 \\
(0.1948)\end{array}$ & $\begin{array}{l}1.6064^{* *} \\
(0.6839)\end{array}$ & $\begin{array}{c}0.3281^{* *} \\
(0.157)\end{array}$ \\
\hline
\end{tabular}

HAC standard errors in parentheses. ${ }^{*} p<0.10,{ }^{* *} p<0.05,{ }^{* * *} p<0.01$. 
The results of the endogeneity-robust estimators provide mixed results for the stock wealth effect. In all the specifications presented in Tables 8-10, only Canada and Switzerland consistently show statistically significant, positive, but weak stock wealth effects. Sweden shows similar stock wealth effect pattern in Tables 9 and 10. On the opposite side, Australia, Finland, Italy, and Japan show statistically significant, weak, and negative stock wealth effects in all the specifications. Moreover, while US shows a weak and negative stock wealth effect in Tables 8 and 9, New Zealand shows a negative stock wealth effect in Table 10. The evidence also suggests mixed results for consumption and interest rate linkage. In this respect, CCEMG-2SLS estimator results in Table 9 suggest an identical pattern with the results of our baseline equation results shown in Table 8 as discussed previously. In Table 10, while interest rate has negative relations with consumption in the case of New Zealand and the US, the linkage becomes positive for France and Switzerland.

\subsection{Implications}

The findings on the consumption-wealth effect nexus have important policy implications and should be of interest to policy makers, market participants, and researchers. The first set of evidence, derived from whole and country-level panel analyses, is related to the linkage between stock wealth and consumption. As indicated in Section 4.1, the whole-panel result in Table 7 suggests that stock wealth is negatively correlated with consumption, with insignificant coefficient values in all the specifications. The country-level analysis results in the baseline equation in Table 8 also suggest that the stock wealth effect is positive and statistically significant in one small and one large market-based economy: Switzerland and Canada. Additionally, stock wealth shows a negative relation in mostly bank-based economies, such as Finland, Italy, and Japan, and in Australia and the US, which are market-based economies. Since we find some positive stock market wealth effects in the country-level analysis, we conclude that our findings related to the stock market wealth effect are generally parallel to those of Case et al. (2011). ${ }^{16}$ However, it seems that the stock wealth effects are fairly limited in the relevant countries and rather irrelevant in the remaining countries.

This evidence provides an interesting base for our discussion, as well as suggesting some policy implications. In this respect, defining counter effects between housing wealth and stock market wealth in the case of Australia, Finland, Italy, Japan, and the US in Table 8 implies that it may not be difficult to combine housing-led policies with the stock market due to the relatively weak and less negative impacts of the stock market channel in those countries. It is also interesting to note that, because it indicates positive but small effects in some market-based economies, we may argue that stock wealth does not necessarily induce consumption positively and strongly. For example, the evidence for the UK, the US, and Australia implies that Anglo-Saxon market-based economies do not necessarily enjoy a positive stock market wealth effect despite usual assumptions (i.e., see Paiella 2009). However, in line with the results of some empirical studies in the literature, such as those by Poterba and Samwick (1995), Vissing-Jørgensen (1999), Dynan and Maki (2001), Slacalek (2009), and Case et al. (2011), among others, our results on the negative linkage between stock wealth and consumption are clearly counter-intuitive. The importance of housing market wealth and financial wealth in affecting consumption may be an empirical matter, as highlighted by Case et al. (2011), and the differences in empirical specification may be the cause of the conflicting results (see Cristini and Sevilla 2014). In this respect, the evidence of a negative stock wealth effect can be explained by employing aggregate-level data (see Bostic et al. 2009; Carroll et al. 2011; Helander 2014) and our other modelling features, as also emphasized in similar studies (i.e., see Ludvigson and Steindel 1999; Case et al. 2005, 2011). The intuition underlying the controversy surrounding the negative or barely positive relationship between consumption

16 Case et al. (2011) found that the estimated coefficient for stock market wealth has a negative sign. The authors further discussed their finding of 'at best' weak evidence of a link between stock market wealth and consumption. In contrast, they also found strong evidence that variations in housing-market wealth have important effects on consumption. 
and the stock wealth effect may be explained by various other factors, as both suggested in the theoretical/empirical literature and discussed in Section 2.2, such as the shared and uneven distribution of income and financial wealth, the level and distribution of debt, the wealth-related spending pattern and generally lower marginal propensity to consume of wealthier people, the role of consumer confidence, the negative impacts of fluctuations, the characteristic of the perceived shocks (transitory vs. permanent), and the short/long-term reactions of consumers and the policies of economic agents during specifically unstable periods. As discussed lately by Case et al. (2011), this counter evidence may also be related to the negative impact of cycles and crises. Therefore, we may speculate that rising fluctuations in the global economy and major economies during the 1970 Q1 to 2015 Q4 period arising from various catastrophic economic/financial shocks, such as the post-Bretton Woods period (1973-), oil crisis (1982), US savings and loan crisis (1980s-1990s), Asian-Russian financial crisis (1997-1998), dotcom bubble (2000-2002), global financial crisis (2007-2010), and various country-specific financial failures might collectively form a background for the negative stock market wealth channel.

The second set of evidence is related to the linkage between housing wealth and consumption. Despite mixed but weak results on the stock wealth effect, the evidence of a strong housing wealth effect in the whole and cross-country panels suggests that housing is a powerful asset for transmission channels irrespective of the size, financial structure, and geographic locations of the analysed economies. Moreover, in line with several empirical studies and the theoretical background (see, among others, Case et al. 2001; Bertaut 2002; Dvornak and Kohler 2003; Benjamin et al. 2004; Ludwig and Sløk 2004; Case et al. 2005; Kishor 2007; Mishkin 2007; Sierminska and Takhtamanova 2007; Bostic et al. 2009; Slacalek 2009; Carroll et al. 2011; Simo-Kengne et al. 2013), we validate the assertion that the housing wealth effect is larger than the stock wealth effect. Taking into account the various economic shocks and stock/housing market cycles during our observation period, we may argue that the positive housing wealth channel shows long-term characteristics in the analysed countries.

This outcome may be related to several mutual factors, such as the importance of housing as the asset class and the level of mortgage market completeness with highly developed financial systems ${ }^{17}$ in the analysed advanced countries. We may also speculate that the generally larger diffusiveness and concentration of the wealth in the housing-compared with the stock-market may make the housing wealth channel more efficient in terms of inducing consumption. In this respect, broader dispersion of housing wealth may result in a more middle-class-oriented wealth-spending pattern compared with the characteristics of stock market wealth. Therefore, depending on the country-specific conditions, we may argue that the more dispersed and democratized wealth accumulation represented by the housing wealth channel may result in a more stable long-term consumption pattern. As for the important policy implication of the above evidence, we may conclude, however, that it may depend on country-specific conditions; policy makers may stimulate households' final consumption through the housing wealth channel rather than the stock market wealth channel for countries showing a positive housing wealth-consumption linkage.

The country-level evidence suggests that the direction and size of the wealth effect shows variations, probably due to the impact of the country-specific economic structures. We may focus on six interesting cases. Taking into account the fact that Canada, Sweden, and Switzerland have positive transmission channels in both the housing and the stock market in Tables 9 and 10, the policy makers in those countries may have more options to implement successful monetary and growth policies by specifically focusing on the linkage between housing wealth and consumption. The housing wealth effect in Japan is positive but generally low in all the specifications. Therefore, since the benefits of the housing (and real estate) wealth effect may be oversold in this country, policy makers

17 For example, the ECB (2009) argued that the transmission of house price shocks through the macroeconomy is affected by the completeness of the mortgage market institutions in terms of offering a wide spectrum of financial products. 
in Japan may carefully analyse the potential costs (i.e., the Japanese real estate bubble in 1990s) of real estate-led consumption/growth policies. Moreover, sizable positive housing wealth effects in the UK and US imply that the policy makers in these countries may always use the housing market to induce consumption. In line with some studies in the empirical literature such as Kerdrain (2011) and Jaramillo and Chailloux (2015), we report no statistically significant relationship between interest rates and consumption in the whole panel, but we present evidence of strong cross-country heterogeneity in the country level analyses. Country-level evidence of small effects of interest rates on consumption also seems parallel to some studies in the empirical literature, as discussed by Kapoor and Ravi (2009). Although our primary interest does not focus on consumption-interest rates linkage, this evidence implies that the interest rates may not be a powerful policy tool with which to induce consumption in the long-term for advanced countries.

Existing studies, such as Dreger and Reimers (2012), Hui et al. (2012), and Apergis et al. (2014), may reveal a cointegration relationship between income, housing wealth, and stock wealth. Involving interest rates as the additional variable in the cointegration analysis, our study suggests an extension. So, as the third set of evidence, the results suggest a long-run cointegration relationship between consumption, income, housing wealth, stock wealth, and interest rate. Showing a long term relationship among consumption, income, and wealth components, this result may be also partially interpreted as supportive evidence for the life cycle theory in line with the arguments of Gali (1990) and Bertaut (2002).

Moreover, the evidence suggests bidirectional causality between consumption and housing wealth, stock market wealth, and income. Bidirectional causalities among these variables have also been documented by Shirvani et al. (2012), Apergis et al. (2014), and Ohman and Yazdanfar (2017). These latter findings support the importance of the wealth effects of housing and stock markets and imply that consumption, income, stock wealth, and housing wealth have complicated relations. Moreover, the study also documents bidirectional causality between interest rate and consumption and income, and also between income and housing wealth. In line with its theoretical context, these outcomes also imply that the policies on income and interest rates may eventually be effective on consumption. From the policy perspective, in addition to defining both a positive and a larger wealth effect for housing, providing evidence of cointegration among variables and bidirectional causality specifically between consumption and housing wealth suggests that the housing market is the key to consumption growth in the long run. Therefore, this evidence provides further support for housing-oriented policies to boost consumption in the analysed countries.

Some care should be taken when interpreting these results. The benefits of supporting housing markets may have limits in general. The recent subprime mortgage market crisis reveals that microand macro-prudential regulations in mortgage finance are important to keep the positive housing wealth effect on consumption sustainable. Moreover, from the price risk perspective, it is also important to note that housing-led policies may induce economic growth through the consumption channel; however, policy makers should be careful regarding potential bubble formation in housing (beside stock markets) and declining housing affordability, which may arise from rising property prices. As is well-documented in the literature, housing-led economic policies may eventually result in an overpriced housing market with various irrationalities.

\section{Conclusions}

In this study, we explored how household real per capita final consumption expenditure (consumption) responds to changes in the net real per capita national disposable income (income) and interest rates but essentially changes in terms of housing and stock market wealth for 11 advanced OECD countries-Australia, Canada, Finland, France, Italy, Japan, New Zealand, Sweden, Switzerland, the UK, and the US-over the period from 1970 Q1 to 2015 Q4.

We employed various econometric techniques to explore the relations between consumption, income, interest rate, stock wealth, and housing wealth. First, we detected cross-sectional dependence in the data by employing the CD and bias-adjusted LM tests. Second, after detecting cross-sectional 
dependence in the data, we employed the cross-sectionally augmented IPS (CIPS) panel unit root test and determined that all the variables are non-stationary in levels. Third, after concluding that all the series are I(1), we employed the second-generation Durbin-Hausman test for the cointegration. We concluded that the series is cointegrated. Fourth, using Pesaran and Yamagata (2008) slope heterogeneity test, we concluded that the slope is heterogeneous. Fifth, after defining the data as cross-sectionally dependent and heterogeneously sloped, we used the common correlated effects mean group estimator (CCEMG) to estimate the coefficients. To the best of the authors' knowledge, this is the first paper to investigate the linkage between consumption and the wealth effect using a CCEMG estimator. As a robustness check, we reestimated the models utilizing the two-stage least-squares (2SLS) and generalized method of moments (GMM) methodologies. Finally, by employing the Granger causality test introduced by Dumitrescu and Hurlin (2012), we found bidirectional causality between consumption and all the independent variables.

Besides various country-specific implications, we draw four primary conclusions from this study. First, the whole-panel results suggest that income and housing wealth are positively correlated, and stock market wealth is negatively correlated with consumption. In this respect, we find that income is the largest component of consumption and that housing wealth has elasticity of around 0.14 , results that are essentially in line with the literature. Second, the country-level evidence suggests a strong housing wealth effect but mixed results concerning the linkage between stock wealth and consumption. In this respect, in the baseline equation, the stock wealth effect was found to be positive and statistically significant in one small and one large market-based economy-Switzerland and Canada-but showed a negative relation in mostly bank-based economies, such as Finland, Italy, and Japan, and in Australia and in the US as market-based economies. However, in line with the results of some empirical studies in the literature, such as Poterba and Samwick (1995), Vissing-Jørgensen (1999), Dynan and Maki (2001), Slacalek (2009), and Case et al. (2011), among others, our results on the negative linkage between stock wealth and consumption are clearly counter-intuitive. The employment of aggregate-level data (see Bostic et al. 2009; Carroll et al. 2011; Helander 2014) and some modelling features may play a role in this outcome. Defining the long-term benefits of the stock market in the sense of inducing consumption is rather weak and even negative in some cases, and may imply that the stock market may not be a long-term policy-making priority for inducing consumption in advanced countries.

Third, the evidence of a strong housing wealth effect on the whole and cross-country panel results suggest that housing is a powerful asset transmission channel irrespective of the size, financial structure, and geographic location of the analysed economies. In line with several studies in the literature, we also validate the idea that the housing wealth effect is larger than the stock wealth effect. On the other hand, we may note that the country-level variations in both wealth effects are probably related to the country-specific economic conditions. It seems that generally larger diffusiveness and concentration of the wealth in housing-compared with the stock-market and the high level of mortgage market completeness may make the housing wealth channel more efficient in terms of inducing consumption in advanced countries. Therefore, policy makers may stimulate household final consumption through the housing wealth channel rather than the stock market wealth channel in advanced economies. Finally, we find a long-run cointegration relationship between consumption, income, interest rate, housing wealth, and stock wealth. The evidence also suggests bidirectional causality between consumption and both housing wealth and stock wealth beside income and interest rates. This latter evidence collectively confirms from consumption-wealth effect perspective that the housing market is the key to consumption growth in the long run.

The literature on the consumption-wealth effect nexus lacks consensus, perhaps due to differences in the choice of variable, data, period, and modelling approaches. Thus, there is scope for further research by changing these components according to the preferences. As a future avenue of research, researchers may focus on how asset transmission channels may work depending on the expenditure types, such as spending on (non-)durables and luxury goods. This analysis may provide refined knowledge regarding the interactions between housing and stock market wealth and different 
consumption types. Another line of research may focus on why countries show different patterns in the consumption-wealth effect nexus and what the components of lower/higher/no wealth effects are in stock and housing markets. We also suggest analysing the relations between consumption and stock/housing market wealth during different sub-periods to show specifically the impact of local/global economic cycles. Also, using additional variables such as unemployment rate and saving rate, and quantifying the impacts of taxes, policies, consumer confidence, and cycles may provide further insight into the understanding of consumption function.

Author Contributions: All authors collectively contributed to the research strategies of the paper. In personal level, E.A. contributed Sections 2.1, 2.2 and 3.1, G.M. contributed Sections 2.2 and 2.4. B.S.A. developed modelling strategy and hence specifically contributed Sections 3.1 and 3.2. Finally, Y.C. contributed whole paper but specifically focused on Sections $1-5$.

Conflicts of Interest: The authors declare no conflict of interest.

\section{Appendix}

Table A1. Data Information.

\begin{tabular}{ccccc}
\hline Variable & Source & $\begin{array}{c}\text { Unit of } \\
\text { Measure/Base Year }\end{array}$ & \multicolumn{1}{c}{ Variable Description } & \multicolumn{1}{c}{ Data Construction } \\
\hline $\begin{array}{c}\text { Household final } \\
\text { consumption } \\
\text { expenditure }\end{array}$ & OECD & $\begin{array}{c}\text { Quarterly, constant } \\
\text { 2010 U.S. Dollars. }\end{array}$ & $\begin{array}{l}\text { Natural log of household real per } \\
\text { capita final consumption } \\
\text { expenditures }\end{array}$ & $\begin{array}{l}\text { Dividing household final } \\
\text { consumption expenditures by } \\
\text { population, deflating by CPI, } \\
\text { and taking natural logarithm. }\end{array}$ \\
\hline $\begin{array}{c}\text { Net national } \\
\text { disposable income }\end{array}$ & OECD & $\begin{array}{c}\text { Annual, constant } \\
\text { 2010 U.S. Dollars. }\end{array}$ & $\begin{array}{l}\text { Natural log of net real per capita } \\
\text { national disposable income }\end{array}$ & $\begin{array}{l}\text { Transforming into quarterly series by } \\
\text { linear interpolation, dividing by } \\
\text { population, deflating by CPI, } \\
\text { and taking natural logarithm. }\end{array}$ \\
\hline Share Price Index & OECD & $\begin{array}{c}\text { Quarterly, } \\
2010=100 .\end{array}$ & $\begin{array}{l}\text { Natural log of real share price index } \\
\text { (proxy of stock market wealth) }\end{array}$ & $\begin{array}{l}\text { Deflating share price index by CPI } \\
\text { and taking natural logarithm. }\end{array}$ \\
\hline House Price Index & OECD & $\begin{array}{c}\text { Quarterly, } \\
2010=100 .\end{array}$ & $\begin{array}{l}\text { Natural log of real house price index } \\
\text { (proxy of housing market wealth) }\end{array}$ & $\begin{array}{l}\text { Deflating house price index by CPI } \\
\text { and taking natural logarithm. }\end{array}$ \\
\hline Population & World Bank & $\begin{array}{c}\text { Annual, } \\
\text { thousands people. }\end{array}$ & Population & $\begin{array}{l}\text { Transformed into quarterly series by } \\
\text { linear interpolation. }\end{array}$ \\
\hline $\begin{array}{c}\text { Consumer Price } \\
\text { Index }\end{array}$ & OECD & $\begin{array}{c}\text { Quarterly, } \\
2010=100\end{array}$ & Consumer price index & Employed as nominal values. \\
\hline Qnterest Rates & OECD & Quarterly & Short term interest rate & \\
\hline
\end{tabular}

\section{References}

Aftalion, Florin. 1997. Que peut-on attendre de l'Euro? Revue Politique et Parlementaire 1: 22-38.

Albacete, Nicolas, and Peter Lindner. 2017. How strong is the wealth channel of monetary policy transmission? A microeconometric evaluation for Austria. Monetary Policy \& the Economy 2017: 32-53.

Allen, Franklin, and Douglas Gale. 2000. Comparing Financial Systems. Cambridge: MIT Press.

Ando, Albert, and Franco Modigliani. 1963. The life cycle hypothesis of saving: Aggregate implications and tests. American Economic Review 53: 55-84.

Andreoni, James. 1995. Warm-Glow vs. Cold-Prickle: The Effect of Positive and Negative Framing on Cooperation in Experiments. Quarterly Journal of Economics 110: 1-21. [CrossRef]

Aoki, Kosuke, James Proudman, and Gertjan Vlieghe. 2004. House prices, consumption and monetary policy: A financial accelerator approach. Journal of Financial Intermediation 13: 414-35. [CrossRef]

Apergis, Nicholas, Beatrice Simo-Kengne, and Rangan Gupta. 2014. The Long-Run Relationship between Consumption, House Prices and Stock Prices in South Africa: Evidence from Provincial-Level Data. Journal of Real Estate Literature 22: 83-99.

Arkes, Hal R., Cynthia A. Joyner, Mark V. Pezzo, Jane Gradwohl Nash, Karen Siegel-Jacobs, and Eric Stone. 1995. The Psychology of Windfall Gains. Organizational Behavior and Human Decision Processes 59: 331-47. [CrossRef]

Aron, Janine, and John Muellbauer. 2013. Housing wealth, credit conditions and consumption: Evidence from South Africa. Review of Income and Wealth 59: 161-96. [CrossRef] 
Asprem, Mads. 1989. Stock prices, asset portfolios and macroeconomic variables in ten European countries. Journal of Banking \& Finance 13: 589-612.

Atasoy, Burak Sencer. 2017. Testing the environmental Kuznets curve hypothesis across the U.S.: Evidence from panel mean group estimators. Renewable and Sustainable Energy Reviews 77: 731-47. [CrossRef]

Attanasio, Orazio, Laura Blow, Robert Hamilton, and Andrew Leicester. 2009. Consumption, House Prices, and Expectations. Economica New Series 76: 20-50. [CrossRef]

Aye, Goodness C., Rangan Gupta, and Mampho P. Modise. 2012. Do stock prices impact consumption and interest rates in South Africa? Evidence from a time varying vector autoregressive model. Journal of Emerging Market Finance 14: 176-96. [CrossRef]

Bajari, Patrick, C. Lanier Benkard, and John Krainer. 2003. House Prices and Consumer Welfare. NBER Working Paper 9783. Cambridge: National Bureau of Economic Research.

Barrell, Ray, Mauro Costantini, and Iris Meco. 2015. Housing wealth, financial wealth, and consumption: New evidence for Italy and the UK. International Review of Financial Analysis 42: 316-23. [CrossRef]

Belsky, Eric, and Joel Prakken. 2004. Housing Wealth Effects: Housing's Impact on Wealth Accumulation, Wealth Distribution and Consumer Spending. National Center for Real Estate Research Report W04-13. Boston: Harvard University.

Benjamin, John D., Peter Chinloy, and G. Donald Jud. 2004. Real estate versus financial wealth in consumption. Journal of Real Estate Finance and Economics 29: 341-54. [CrossRef]

Bertaut, Carol. 2002. Equity Prices, Household Wealth, and Consumption Growth in Foreign Industrial Countries: Wealth Effects in the 1990s; IFDP Working Paper 724; Washington, DC: Federal Reserve Board.

Blackburne, Edward F., and Mark W. Frank. 2007. Estimation of nonstationary heterogeneous panels. Stata Journal 7: 197-208.

Blanchard, Olivier J., and Stanley Fisher. 1989. Lectures on Macro-Economics. Cambridge: MIT Press.

Boone, Laurence, and Nathalie Girouard. 2002. The stock market, the housing market and consumer behaviour. OECD Economic Studies 2002: 175-200. [CrossRef]

Boone, Laurence, Claude Giorno, and Pete Richardson. 1998. Stock Market Fluctuations and Consumption Behaviour. OECD Economics Department Working Papers No. 208. Paris: OECD.

Bootle, R. 1981. How important is it to Defeat Inflation-The Evidence. Three Banks Review 132: $23-47$.

Borio, Claudio E. V. 1996. Credit Characteristics and the Monetary Policy Transmission Mechanism in Fourteen Industrial Countries: Facts, Conjectures and Some Econometric Evidence. In Monetary Policy in a Converging Europe. Edited by Alders Koos. Norwell: Kluwer Academic Publishers.

Bostic, Raphael, Stuart Gabriel, and Gary Painter. 2009. Housing wealth, financial wealth, and consumption: New evidence from micro data. Regional Science and Urban Economics 39: 79-89. [CrossRef]

Buiter, Willem H. 2008. Housing Wealth Isn't Wealth. NBER Working Paper No. 14204. Available online: http: / / www.nber.org/papers/w14204.pdf (accessed on 26 March 2018).

Calomiris, Charles, Stanley D. Longhofer, and William Miles. 2009. The (Mythical?) Housing Wealth Effect. NBER Working Paper. No. 15075. Available online: http:/ / www.nber.org/papers/w15075 (accessed on 26 March 2017).

Campbell, John Y., and Joao F Cocco. 2007. How do house prices affect consumption? Evidence from micro data. Journal of Monetary Economics 54: 591-621. [CrossRef]

Campbell, John Y., and N. Gregory Mankiw. 1989. Consumption, Income and Interest Rates: Reinterpreting the Time Series Evidence. In NBER Macroeconomics Annual. NBER Working Paper Series, Working Paper No. 2924; Cambridge: MIT Press, vol. 4, pp. 185-216.

Carroll, Christopher. 2004. Housing Wealth and Consumption Expenditure. Baltimore: Johns Hopkins University.

Carroll, Christopher D., Misuzu Otsuka, and Jiri Slacalek. 2011. How large are housing and financial wealth effects? A new approach. Journal of Money, Credit and Banking 43: 55-79. [CrossRef]

Case, Karl E., John M. Quigley, and Robert J. Shiller. 2001. Comparing Wealth Effects: The Stock Market versus the Housing Market. National Bureau of Economic Research Working Paper No. 8606. Cambridge: NBER.

Case, Karl E., John M. Quigley, and Robert J. Shiller. 2005. Comparing wealth effects: The stock market versus the housing market. Advances in Macroeconomics 5. [CrossRef]

Case, Karl E., John M. Quigley, and Robert J. Shiller. 2011. Wealth Effects Revisited 1978-2009. NBER Working Paper No. 16848. Cambridge: NBER.

Catte, Pietro, Nathalie Girouard, Robert W. R. Price, and Christophe Andre. 2004. Housing Markets, Wealth and the Business Cycle. OECD Working Paper. No. 394. Paris: OECD. 
Chen, Jie. 2006. Housing Wealth and Aggregate Consumption in Sweden. Uppsala University Economics Working Paper No. 2006:16. Uppsala: Uppsala University.

Chudik, Alexander, and M. Hashem Pesaran. 2013. Large Panel Data Models with Cross-Sectional Dependence: A Survey. Globalization and Monetary Policy Institute Working Paper 153. Dallas: Federal Reserve Bank of Dallas.

Ciarlone, Alessio. 2011. Housing wealth effect in emerging economies. Emerging Markets Review 12: $399-417$. [CrossRef]

Cristini, Annalisa, and Almudena Sevilla. 2014. Do house prices affect consumption? A re-assessment of the wealth hypothesis. Economica 81: 601-25. [CrossRef]

Davis, Morris A., and Michael G. Palumbo. 2001. A Primer on the Economics and Time Series Econometrics of Wealth Effects." Federal Reserve Board; Finance and Economics Discussion Paper No. 2001-09; Washington, DC: Federal Reserve Board.

De Bandt, Olivier, Thomas Knetsch, Juan Peñalosa, and Francesco Zollino, eds. 2010. Housing Markets in Europe: A Macroeconomic Perspective. Berlin and Hidelberg: Springer.

DeJuan, Joseph P., John J. Seater, and Tony Wirjanto S. 2006. Testing the permanent-income hypothesis: New evidence from West-German states (Länder). Empirical Economics 31: 613-29. [CrossRef]

Demirgüç-Kunt, Aslı, and Ross Levine. 1999. Bank-Based and Market-Based Financial Systems: Cross-Country Comparisons. Policy Working Paper No. 2143. Washington, DC: World Bank.

Demirgüç-Kunt, Asl1, Erik Feyen, and Ross Levine. 2011. The Evolving Importance of Banks and Securities Markets. Policy Research Working Paper No. 5805. Washington, DC: World Bank.

Di Maggio, Marco, Amir Kermani, Benjamin J. Keys, Tomasz Piskorski, Rodney Ramcharan, Amit Seru, and Vincent Yao. 2017. Interest Rate Pass-Through: Mortgage Rates, Household Consumption, and Voluntary Deleveraging. American Economic Review 107: 3550-88. [CrossRef]

Dornbusch, Rudi, and Stanley Fischer. 1990. Macroeconomics, 5th ed. New York: McGraw-Hill College.

Dreger, Christian, and Hans-Eggert Reimers. 2012. The long-run relationship between private consumption and wealth: Common and idiosyncratic effects. Portuguese Economic Journal 11: 21-34. [CrossRef]

Duesenberry, James S. 1949. Income, Saving and the Theory of Consumer Behavior. Cambridge: Harvard University Press.

Dumitrescu, Elena-Ivona, and Christophe Hurlin. 2012. Testing for Granger non-causality in heterogeneous panels. Economic Modelling 29: 1450-60. [CrossRef]

Dvornak, Nikola, and Marion Kohler. 2003. Housing Wealth, Stock Market Wealth and Consumption: A Panel Analysis for Australia; Research Discussion Paper, No. 2003-07; Sydney: Economic Research Department, Reserve Bank of Australia.

Dynan, Karen E., and Dean M. Maki. 2001. Does Stock Market Wealth Matter for Consumption? Federal Reserve System, Discussion Paper Series; 2001-2004 (May). Cleveland: Federal Reserve Bank of Cleveland.

ECB. 2009. Housing wealth and private consumption in the euro area. Monthly Bulletin, January, 59-71.

Edison, Hali, and Torsten Sløk. 2001. Wealth Effects and the New Economy. IMF Working Paper 01/77. Washington, DC: International Monetary Fund.

Engelhardt, Gary V. 1996. House prices and home owner saving behavior. Regional Science and Urban Economics 26: 313-36. [CrossRef]

Fereidouni, Hassan Gholipour, and Reza Tajaddini. 2015. Housing Wealth, Financial Wealth and Consumption Expenditure: The Role of Consumer Confidence. The Journal of Real Estate Finance and Economics 54: 216-36. [CrossRef]

Floam, Allison. 2005. Comparing Housing Wealth and Stock Wealth Effects on Consumption. Wharton Research Scholars. 24. Available online: https://repository.upenn.edu/wharton_research_scholars/24 (accessed on 12 March 2018).

Floden, Martin. 2001. The effectiveness of government debt and transfers as insurance. Journal of Monetary Economics 48: 81-108. [CrossRef]

Friedman, Milton. 1948. A Monetary and Fiscal Framework for Economic Stability. American Economic Review 38: 245-64.

Friedman, Milton. 1957. A Theory of the Consumption Function. National Bureau of Economic Research, General Series, No. 63. Princeton: Princeton University Press. 
Gali, Jordi. 1990. Finite Horizons, Life-Cycle Savings, and Time-Series Evidence on Consumption. Journal of Monetary Economics 26: 433-52. [CrossRef]

Gambacorta, Leonardo, Jing Yang, and Kostas Tsatsaronis. 2014. Financial structure and growth. BIS Quarterly Review, 21-35.

Gonzalo, Jesus, and Serena Ng. 2001. A systematic framework for analyzing the dynamic effects of permanent and transitory shocks. Journal of Economic Dynamics and Control 25. [CrossRef]

Granger, Clive W. J. 1969. Investigating causal relations by econometric models and cross-spectral methods. Econometrica 36: 424-38. [CrossRef]

Gylfason, Thorvaldur. 1981. Interest rates, inflation and the aggregate consumption function. The Review of Economics and Statistics 63: 233-45. [CrossRef]

Hall, Robert. E. 1978. Stochastic implications of the life cycle-permanent income hypothesis: Theory and evidence. Journal of Political Economy 86: 971-87. [CrossRef]

Hall, Robert E. 1988. Intertemporal Substitution in Consumption. Journal of Political Economy 96: 339-57. [CrossRef]

Hall, Robert E., and Frederic S. Mishkin. 1982. The sensitivity of consumption to transitory income: Estimates from panel data on households. Econometrica 50: 461-81. [CrossRef]

Hansen, Hermann-Joseph. 1996. The Impact of Interest Rates on Private Consumption in Germany. Discussion Paper 3/96. Frankfurt: Deutsche Bundesbank.

Heien, Dale M. 1972. Demographic effects and the multiperiod consumption function. Journal of Political Economy 80: 125-38. [CrossRef]

Heinrichs, Katrin. 2016. German Consumption Inequality. An Evaluation with a Focus on the Financial Crisis. Beiträge zur Jahrestagung des Vereins für Socialpolitik 2016: Demographischer Wandel-Session: Inequality in Germany and Europe, No. A06-V2. Eisenach: German Economic Association.

Helander, Maria. 2014. Estimating Wealth Effects on Consumption in Finland. Working Papers 4/2014. Helsinki: Statistics Finland.

Hernández-Salmarón, Macarena, and Diego Romero-Ávila. 2015. Convergence in Output and Its Sources among Industrialised Countries: A Cross-Country Time-Series Perspective. New York: Springer.

Howard, David H. 1978. Personal saving behavior and the rate of inflation. The Review of Economic and Statistics 60: 547-54. [CrossRef]

Hui, Eddie C. M., Xian Zheng, and Wen-Juan Zuo. 2012. Housing wealth, stock wealth and consumption expenditure: A dynamic analysis for Hong Kong. Property Management 30: 435-48. [CrossRef]

Iacoviello, Matteo. 2011. Housing Wealth and Consumption; International Finance Discussion Paper 1027; Washington, DC: Federal Reserve Board.

Ibrahim, Mansor. H. 2010. House price-stock price relations in Thailand: An empirical analysis. International Journal of Housing Markets and Analysis 3: 69-82. [CrossRef]

Ibrahim, Mansor H., and Muzafar S. Habibullah. 2010. Stock market and aggregate consumption asymmetry: Evidence from Malaysia. Studies in Economics and Finance 27: 19-29. [CrossRef]

Inglesi-Lotz, Roula, Vittorio Peretti, and Rangan Gupta. 2012. Do house prices impact consumption and interest rate in South Africa? Evidence from a Time Varying Vector Autoregressive model. Economics, Financial Markets and Management 7: 101-20.

Im, Kyung S., M. Hashem Pesaran, and Yongcheol Shin. 2003. Testing for unit roots in heterogeneous panels. Journal of Econometrics 115: 53-74. [CrossRef]

Jaffee, Dwight, and Joseph E. Stiglitz. 1990. Credit rationing. In Handbook of Monetary Economics. Edited by B. M. Friedman and F. H. Hahn. New York: Elsevier Science Publishers, vol. 2.

Jaramillo, Laura, and Alexandre Chailloux. 2015. It's Not All Fiscal: Effects of Income, Fiscal Policy, and Wealth on Private Consumption. Working Paper. Washington, DC: IMF.

Jawadi, Fredj, and Ricardo M. Sousa. 2014. The relationship between consumption and wealth: A quantile regression approach. Revue D'économie Politique 124: 637-50. [CrossRef]

Jawadi, Fredi, Richard Soparnot, and Ricardo M. Sousa. 2015. Assessing financial and housing wealth effects through the lens of a nonlinear framework. Research in International Business and Finance 39: 840-50. [CrossRef]

Juhl, Ted, and Oleksandr Lugovskyy. 2014. A test for slope heterogeneity in fixed effects model. Econometric Reviews 33: 906-35. [CrossRef]

Kapetanios, George, M. Hashem Pesaran, and Takashi Yamagata. 2011. Panels with non-stationary multifactor error structures. Journal of Econometrics 160: 326-48. [CrossRef] 
Kapoor, Mudit, and Shamika Ravi. 2009. The Effect of Interest Rate on Household Consumption: Evidence from a Natural Experiment in India. February 20. Available online: https:/ /ssrn.com/abstract=1346813 (accessed on 10 March 2018). [CrossRef]

Kennickell, Arthur B., and Martha Starr-McCluer. 1997. Retrospective Reporting of Household Wealth: Evidence from the 1983-89 Survey of Consumer Finances. Journal of Business and Economic Statistics 15: 452-63.

Kerdrain, Clovis. 2011. How Important is Wealth for Explaining Household Consumption Over the Recent Crisis?: An Empirical Study for the United States, Japan and the Euro Area. OECD Economics Department Working Papers, No. 869. Paris: OECD Publishing. [CrossRef]

Keynes, John M. 1936. The General Theory of Employment, Interest and Money. London: Macmillan.

Kishor, N. Kundan. 2007. Does consumption respond more to housing wealth than to financial market wealth? If so, why? The Journal of Real Estate Finance and Economics 35: 427-48. [CrossRef]

Kuznets, Simon. 1946. Introduction to "National Income: A Summary of Findings". In National Income: A Summary of Findings. Cambridge: NBER, pp. 1-2.

Labhard, Vincent, Gabriel Sterne, and Chris Young. 2005. The Wealth Effects on Consumption in Industrialized Countries. Bank of England Working Papers, No. 275. London: Bank of England.

Lee, Ming-Tee, Chyi L. Lee, Ming L. Lee, and Chien-Ya Liao. 2017. Price linkages between Australian housing and stock markets: Wealth effect, credit effect or capital switching? International Journal of Housing Markets and Analysis 10: 305-23. [CrossRef]

Lettau, Martin, and Sydney C. Ludvigson. 2004. Understanding trend and cycle in asset values: Re-evaluating the wealth effect on consumption. American Economic Review 94: 276-99. [CrossRef]

Levine, Ross. 2002. Bank-based or Market-based Financial Systems: Which Is Better? Journal of Financial Intermediation 11: 398-428. [CrossRef]

Ludvigson, Sydney, and Charles Steindel. 1999. How Important Is the Stock Market Effect on Consumption? FRBNY Economic Policy Review 5: 29-51.

Ludwig, A., and T. Sløk. 2002. The Impact of Changes in Stock Prices and House Prices and House Prices on Consumption in OECD Countries. Working Paper WP/02/1. Washington, DC: IMF.

Ludwig, Alexander, and Torsten Sløk. 2004. The relationship between stock prices, house prices and consumption in OECD countries. Topics in Macroeconomics 4: 1-24. [CrossRef]

MacDonald, Garry, Andy Mullineux, and Rudra Sensarma. 2011. Asymmetric effects of interest rate changes: The role of the consumption-wealth channel. Applied Economics 43: 1991-2001. [CrossRef]

Mariger, Randall P. 1986. Consumption Behavior and the Effects of Government Fiscal Policies. No. 158. Cambridge: Harvard University Press.

Mehra, Yash P. 2001. The wealth effect in empirical life-cycle aggregate consumption equations. Economic Quarterly 87: 45-67.

Mishkin, Frederic S. 1976. Illiquidity, consumer durable expenditure, and monetary policy. The American Economic Review 66: 642-54.

Mishkin, Frederic. 2007. Housing and the Monetary Transmission Mechanism; Working Paper, Finance and Economic Discussion Series; Washington, DC: Federal Reserve Board.

Modigliani, Franco, and Richard Brumberg. 1954. Utility Analysis and the Consumption Function: An Interpretation of Cross-Section Data. In Post-Keynesian Economics. Edited by K. K. Kurihara. New Brunswick: Rutgers University Press, pp. 388-436.

Modigliani, Franco, and Richard Brumberg. 1979. Utility analysis and the consumption function: An attempt at integration. In The Collected Papers of Franco Modigliani. Edited by A. Abel. Cambridge: MIT Press, vol. 2.

Modigliani, Franco, and Ezio Tarantelli. 1975. The Consumption Function in the Developing Economy and the Italian Experience. American Economic Review 65: 825-42.

Modigliani, Franco, Charles Steindel, Saul H. Hymans, and F. Thomas Juster. 1977. Is a Tax Rebate an Effective Tool for Stabilization Policy? Brookings Papers on Economic Activity 1: 177-203. [CrossRef]

Muellbauer, John N. 2007. Housing, Credit and Consumer Expenditure. In Housing, Housing Finance and Monetary Policy. Kansas City: Jackson Hole Symposium, Federal Reserve Bank of Kansas City, pp. 267-334.

Newey, Whitney, and Kenneth West. 1987. Hypothesis testing with efficient method of moments estimation. International Economic Review 28: 777-87. [CrossRef]

O'Connell, Paul G. J. 1998. The overvaluation of purchasing power parity. Journal of International Economics 44: 1-19. [CrossRef] 
Ohman, Peter, and Darush Yazdanfar. 2017. The nexus between stock market index and apartment and villa prices: Granger causality test of Swedish data. International Journal of Housing Markets and Analysis 10: 450-67. [CrossRef]

Paiella, Monica. 2007. Does wealth affect consumption? Evidence for Italy. Journal of Macroeconomics 29: 189-205. [CrossRef]

Paiella, Monica. 2009. The Stock Market, Housing and Consumer Spending: A Survey of the Evidence on Wealth Effects. Journal of Economic Surveys 23: 947-73. [CrossRef]

Paradiso, Antonio, Paolo Casadio, and Bhaskara B. Rao. 2012. US inflation and consumption: A long-term perspective with a level shift. Economic Modelling 29: 1837-49. [CrossRef]

Pedroni, Peter. 1999. Critical Values for Cointegration Tests in Heterogeneous Panels with Multiple Regressors. Oxford Bulletin of Economics and Statistics 61: 653-670. [CrossRef]

Peltonen, Tuomas A., Ricardo M. Sousa, and Isabel S. Vansteenkiste. 2012. Wealth effects in emerging market economies. International Review of Economics and Finance 24: 155-66. [CrossRef]

Pesaran, M. Hashem. 2004. General Diagnostic Tests for Cross Section Dependence in Panels. Cambridge Working Papers in Economics 0435. Cambridge: Faculty of Economics, University of Cambridge.

Pesaran, M. Hashem. 2006. Estimation and inference in large heterogeneous panels with a multifactor error structure. Econometrica 74: 967-1012. [CrossRef]

Pesaran, M. Hashem. 2007. A simple panel unit root test in the presence of cross-section dependence. Journal of Applied Econometrics 22: 265-312. [CrossRef]

Pesaran, M. Hashem, and Ron Smith. 1995. Estimating long-run relationships from dynamic heterogeneous panels. Journal of Econometrics 8: 79-113. [CrossRef]

Pesaran, M. H., and Takashi Yamagata. 2008. Testing slope homogeneity in large panels. Journal of Econometrics 142: 50-93. [CrossRef]

Pesaran, M. Hashem, Yongcheol Shin, and Ron Smith. 1999. Pooled mean group estimation of dynamic heterogeneous panels. Journal of the American Statistical Association 94: 621-34. [CrossRef]

Pesaran, M. Hashem, Aman Ullah, and Takashi Yamagata. 2008. A bias-adjusted LM test of error cross-section independence. Econometrics Journal 11: 105-27. [CrossRef]

Pichette, Lise, and Dominique Tremblay. 2003. Are Wealth Effects Important for Canada? Bank of Canada Working Paper 2003-30. Ottawa: Bank of Canada.

Poterba, James M. 2000. Stock market wealth and consumption. Journal of Economic Perspectives 14: 99-118. [CrossRef]

Poterba, James, and Andrew Samwick. 1995. Stock Ownership Patterns, Stock Market Fluctuations, and Consumption. Brookings Papers on Economic Activity 2: 295-357. [CrossRef]

Rapach, David E., and Jack K. Strauss. 2006. The long-run relationship between consumption and housing wealth in the eight district states. Regional Economic Development 2: 140-47.

Romer, Christina D. 1990. The great crash and the onset of the great depression. The Quarterly Journal of Economics 105: 597-624. [CrossRef]

Sarafidis, Vasilis, and Donald Robertson. 2009. On the impact of error cross-sectional dependence in short dynamic panel estimation. The Econometrics Journal 12: 62-81. [CrossRef]

Searle, Beverley. 2011. Recession and housing wealth. Journal of Financial Economic Policy 3: 33-48. [CrossRef]

Shefrin, Hersh, and Richard H. Thaler. 1988. The Behavioral Life-Cycle Hypothesis. Economic Inquiry 26: 609-43. [CrossRef]

Shirvani, Hassan, Bahman Mirshab, and Natalya Delcoure. 2012. Stock Prices, Home Prices, and Private Consumption in the US: Some Robust Bilateral Causality Tests. Modern Economy 3: 145-49. [CrossRef]

Sierminska, Eva, and Yelena Takhtamanova. 2007. Wealth Effects out of Financial and Housing Wealth: Cross Country and Age Group Comparisons; Working paper. San Francisco: Federal Reserve Bank of San Francisco.

Simo-Kengne, Beatrice D., Rangan Gupta, and Manoel Bittencourt. 2013. The Impact of House Prices on Consumption in South Africa: Evidence from Provincial-Level Panel VARs. Housing Studies 28: 1133-54. [CrossRef]

Skalin, Joakim, and Timo Teräsvirta. 2002. Modeling asymmetries and moving equilibria in unemployment rates. Macroeconomic Dynamics 6: 202-41. [CrossRef]

Slacalek, Jiri. 2009. What drive personal consumption? The role of housing and financial wealth. The B.E. Journal of Macroeconomics 9. [CrossRef] 
Song, Yu, and Chunlu Liu. 2007. An Input-Output Approach for Measuring Real Estate Sector Linkages. Journal of Property Research 24: 71-91. [CrossRef]

Šonje, Amina A., Anita C. Časni, and Maruska Vizek. 2014. The effect of housing and stock market wealth on consumption in emerging and developed countries. Economic Systems 38: 433-50. [CrossRef]

Sousa, Ricardo M. 2009. Wealth Effects on Consumption Evidence from the Euro Area. Working Paper No. 1050. Frankfurt: European Central Bank.

Sousa, Ricardo. 2010. Housing wealth, financial wealth, money demand and policy rule: Evidence from the euro area. The North American Journal of Economics and Finance 21: 88-105. [CrossRef]

Springer, William L. 1977. Consumer spending and the rate of inflation. The Review of Economics and Statistics 59: 299-306. [CrossRef]

Steinberg, Richard, Mark Wilhelm, Patrick Rooney, and Eleanor Brown. 2002. Inheritance and Charitable Donations. Working Paper. Available online: https:// philanthropy.iupui.edu/files/research/inheritance_ and_charitable_donations.pdf (accessed on 18 February 2018).

Steindel, Charles. 1981. The Determinants of Private Saving. In Public Policy and Capital Formation; Washington, DC: Board of Governors of the Federal Reserve System, pp. 101-14.

Swamy, Paravastu A. V. 1970. Efficient inference in a random coefficient regression model. Econometrica 38: 311-23. [CrossRef]

Taylor, Lester D., James Duesenberry, Robert Hall, and George Jaszi. 1971. Saving out of different types of income. Brooking Papers on Economic Activity 2: 383-415. [CrossRef]

Tsai, I.-Chun, Cheng-Feng Lee, and Ming-Chu Chiang. 2012. The Asymmetric Wealth Effect in the US Housing and Stock Markets: Evidence from the Threshold Cointegration Model. The Journal of Real Estate Finance and Economics 45: 1005-20. [CrossRef]

Van Dijk, Dick, Timo Teräsvirta, and Philip Hans Franses. 2002. Smooth transition autoregressive models-A survey of recent developments. Econometric Reviews 21: 1-47. [CrossRef]

Vissing-Jørgensen, Annette. 1999. Limited Stock Market Participation and the Equity Premium Puzzle. New York: Mimeo, Chicago: University of Chicago.

Vizek, Maruška. 2011. The Influence of Stock Market and Housing Wealth on Consumption Expenditures in Transition Countries. Research in Economics and Business: Central and Eastern Europe 3: 50-63.

Westerlund, Joakim. 2008. Panel cointegration tests of the Fisher effect. Journal of Applied Econometrics 23: 193-233. [CrossRef]

Wilcox, James A. 1990. Nominal interest rate effects on real consumption expenditure. Business Economics 25: $31-38$.

Zhou, Xiaorong, Meng-Shiuh Chang, and Karen Gibler. 2015. The asymmetric wealth effects of housing market and stock market on consumption in China. Journal of the Asia Pacific Economy 21: 196-216. [CrossRef] 